\title{
Tissues, Metabolic Pathways and Genes of Key Importance in Lactating Dairy Cattle
}

\author{
Shadi Nayeri ${ }^{1} \cdot$ Paul Stothard $^{1}$
}

Received: 8 April 2016/Revised: 5 September 2016/Accepted: 3 November 2016/Published online: 18 November 2016

(C) The Author(s) 2016. This article is published with open access at Springerlink.com

\begin{abstract}
Milk and dairy products are valuable sources of food for humans. Increased milk yield and changes in milk composition in dairy cows have been achieved through a variety of means including better nutrition, management and genetic selection. This selection can be performed without consideration of the specific genes and genetic variation involved. However, association analysis using dense SNP genotyping panels provides an approach for identifying genomic regions affecting milk production. Coupling physiological and metabolic information with association analysis results can provide greater insight into the specific genetic variants and molecular mechanisms affecting production traits as well as the potential effects of these variants on fertility in dairy cattle. To this end, this review highlights key tissues, metabolic pathways and genes of importance in lactating dairy cattle, particularly early in lactation. Physiological and metabolic adaptations in three key tissues (adipose, mammary gland and liver) are discussed, followed by the important endocrine adaptations during negative energy balance. Key genes mediating metabolic and endocrine adaptations are also highlighted. Finally, genes that account for variation in production traits are presented in relation to the tissues and processes described. Knowledge of the genes and pathways involved will be important for ongoing efforts aimed at finding other
\end{abstract}

Endorsed by Paul Stothard.

Paul Stothard

stothard@ualberta.ca

Shadi Nayeri

nayeri@ualberta.ca

1 Faculty of Agricultural, Food and Nutritional Science, Agriculture/Forestry Centre, University of Alberta, Edmonton, AB T6G 2P5, Canada genes and variants that contribute to milk production and fertility traits. Also, a better understanding of the molecular basis of these traits may lead to more accurate genomic predictions.

Keywords Metabolic pathways - Genes - Lactating dairy cattle $\cdot$ Genome-wide association studies

\section{Introduction}

Humans have recognized milk and dairy products as a valuable source of sustenance since as early as $4000 \mathrm{BC}$ $[8,95]$. Indeed, milk is a source of energy, high quality protein, several key minerals and vitamins [8]. The demand for milk and milk products continues to increase, as does the production capacity of individual cows. For example, from 2005 to 2012, milk production of the Canadian dairy herd increased by $6 \%$, while the number of dairy cows declined by $11 \%$ (www.cdn.ca). Ongoing genetic selection as well as advances in the understanding of the biology of lactation and biosynthesis of milk such as improved understanding of the interrelations between dietary components, digestive processes in the rumen and the regulation of mammary synthesis of milk fat have led to improve in management and substantial increases in milk production and productivity $[8,53]$. This knowledge includes advanced understanding of: the biology of lactation in many mammals (such as goat, sheep, guinea pigs, mice, rats and several other species); the relationship between structure and function of mammary epithelial cells; the biochemical pathways for the synthesis of milk components; the role of hormones in the development of mammary gland and the regulation of mammary gland function $[8,55,72]$. Specific genes and gene variants that account 
for variation in milk production traits have been identified and represent another source of knowledge of the molecular events that can contribute to increases in production. For example, a missense mutation in the DGAT1 gene on chromosome 14 has been identified with major effects on milk composition and fat content in dairy cattle [49]. Two other loci with major effects on milk yield and composition have been identified on chromosomes 6 and 20 and involving the $A B C G 2$ and $G H R$ genes, respectively $[18,29]$. The identification of such genes and variants has been guided in large part by existing knowledge of the roles of certain genes in lactation. This review seeks to present information on tissues, pathways and genes that can guide future studies aimed at understanding the underlying genetic differences that contribute to variation in milk production and fertility traits. Consideration of fertility is important because of the unfavourable correlations between milk yield and fertility traits [120]. Many reproductive disorders including late resumption of ovarian activity or poor conception rate are related to negative energy balance at the peak of lactation in dairy cows $[148,161]$. The identification of the specific genetic variants responsible for variation in these traits should lead to more accurate approaches to genomic selection that work better across generations and breeds [139], and may help us understand or predict potential negative effects on other traits.

Substantial advances in molecular genetics and genomic tools have made the identification of genes and mutations causing simply inherited Mendelian traits relatively straightforward [34, 46]. However, quantitative traits such as milk production in dairy cattle are polygenic, affected by multiple genes and mutations at many sites in the genome [46, 139]. Many of the mutations that affect these quantitative traits have small effects on the phenotype and explain only a small portion of the genetic variance. Therefore, successfully identifying casual mutations and regions affecting these traits is more difficult compared to simple, highly heritable traits [46].

A major goal of quantitative trait loci (QTL) studies in livestock is to identify regions, genes and markers that can be used in breeding programs. A QTL is a section of DNA (a locus) that is correlated with variations in a given phenotype [77]. Identifying the QTL affecting a trait has previously involved low density markers and the application of linkage mapping [46, 106]. Subsequently, through the discovery of markers within new target regions, the use of fine mapping, and the application of high density SNP (single nucleotide polymorphism) panels, the accuracy of QTL detection increased [73]. Fine mapping relies on linkage disequilibrium (LD) between SNPs and unknown casual variants, which are also called quantitative trait nucleotides or QTN [59, 139]. Recent association analyses using dense genetic markers have detected variants associated with milk production-related traits including mammary gland development, and prolactin signalling and involution pathways [57, 59, 122, 146]. After identifying a QTL region, however, it may still be difficult to determine which variants in the region truly affect the trait. Knowledge of the physiology of the trait and of relevant metabolic pathways can be valuable in this regard, as it can highlight genes in the QTL region of potential importance [164]. One of the aims of this review is to facilitate discovery of the mechanisms underlying QTL associated with milk production and fertility-related traits, through highlighting tissues, pathways and genes that are known to play important roles in lactation.

\section{Physiological and Metabolic Adaptations Early in Lactation in Dairy Cattle}

The transition period in dairy cattle presents an enormous metabolic change and challenge to the high-yielding dairy cow [10]. During this time, the energy requirements of the cow increase to accommodate milk production and maintenance [66, 157]. This increase in energy requirements can be partially met by increased feed consumption but is limited due to low dry matter intake and decrease in appetite that tend to occur around this time; the remainder is met by mobilization of body reservoirs [51]. Adipose tissue is the predominant energy reserve in dairy cattle during periods of chronic energy deficit [10, 129]. Through homeostasis mechanisms, adipose tissue optimizes non-esterified fatty acid mobilization to maintain physiological equilibrium and to provide the required energy early in lactation $[5,10,129]$. However, not only is the homeostasis mechanism in adipose tissue important to support changes in a cow's condition, a coordinated change in lipid metabolism of other body tissues is also necessary to support the physiological state of the animal $[5,129]$. This mechanism of regulation is called homeorhesis and applies to nutritionally insensitive (genetically controlled) regulation of lipid metabolism in dairy cattle to support the physiological state of the animal [5, 129]. Liver is the main site for the uptake of serum free fatty acid, increased lipid $\beta$-oxidation and increased gluconeogenesis early in lactation in dairy cattle [5, 129]. Another metabolic adaptation associated with negative energy balance and homeostasis in dairy cows is related to increased use of nutrients and milk lipid droplet in the mammary gland [129]. Therefore, the liver and the mammary gland in dairy cattle are also important tissues in homeostasis and homeorhetic control of lipid metabolism during early lactation $[37,42]$. The physiological and 
metabolic pathways as well as the regulatory components in these three tissues (adipose, liver and mammary gland) are described in subsequent sections.

\section{Adipose Tissue}

Early in lactation, lipid metabolism characteristics change in adipose cells (adipocytes). Endocrine profile changes and mobilization of fatty acid from adipocytes begin [6]. Subsequently, the abundance of non-esterified fatty acids (NEFA) in the serum albumin increases to allow uptake by various tissues [129]. Two main metabolic pathways optimizing NEFA mobilization to maintain physiological equilibrium are lipolysis and lipogenesis [129].

\section{Lipogenesis}

Major sites where lipogenesis generally occurs are the intestinal mucosal cells, the hepatocytes (liver cells) and the adipose tissue [81]. In ruminants, the predominant sites are adipose tissue and the mammary gland of lactating dairy cows [81]. These tissues are responsible for the uptake of pre-formed fatty acids from lipid circulation and for de novo fatty acid synthesis using acetyl-CoA derived from the catabolism of carbohydrates [81, 129]. Most of the carbohydrates in ruminants are fermented into acetate while butyrate and propionate are produced to a lesser extent. As such, acetate is the predominant lipogenic substrate in adipose tissue and the mammary gland for de novo fatty acid synthesis [81, 153].

Acetate is first transformed into pyruvate and then into acetyl-CoA through oxidation within mitochondria [81]. Fatty acid synthesis (lipogenesis) begins with carboxylation of this acetyl-CoA to malonyl-CoA. This reaction is catalyzed by the rate-limiting enzyme, acetyl-CoA carboxylase (ACC) [129]. Malonyl-CoA is then condensed with acetyl-CoA by Acyl-malonyl ACP condensing enzyme to produce a four-unit substrate and $\mathrm{CO}_{2}$ as a result $[12,129]$. The next three steps in fatty acid synthesis are reduction of a keto group at C-3 to a methylene group and formation of butyryl-ACP [12]. With formation of butyrylACP, the first cycle of elongation completes. The elongation cycle continues with condensation of butyryl-ACP with malonyl ACP to form $\mathrm{C}_{6}-\beta$-ketoacyl $\mathrm{ACP}$, and a similar cycle of reactions repeats until $\mathrm{C}_{16}$-acyl ACP is formed; this intermediate is then hydrolyzed by thioesterase to yield palmitate (C16:00) and ACP [12]. In the case of fatty acid uptake from circulating lipids, the second pathway of lipogenesis in the adipocyte starts, which is hydrolysis of plasma triacylglycerides (TAG) by lipoprotein lipase (LPL), producing NEFA and monoacylglycerides $[84,129]$. Depending on the availability of glycerol3-phosphate and monoacylglycerides, TAGs are synthesized through either phosphatidic or monoacylglycerol pathways [84, 129].

\section{Lipolysis}

The hydrolysis of triacylglycerols (TAG) by lipase is activated by signals from molecules such as catecholamine (epinephrine and norepinephrine) and adrenocorticotropic hormones [129]. These hormones trigger membrane receptors that activate adenylate cyclase (Fig. 1). Increased levels of cyclic adenosine monophosphate (cAMP) then simulate protein kinase A. This simulation leads to activation of lipase (hormone-sensitive lipase or HSL), which hydrolyzes fatty acids at the sn- 1 and sn- 3 positions [12]. Then, monoacylglycerol lipase hydrolyzes the remaining fatty acids at the sn- 2 position and generates 3 fatty acids (NFEA) and glycerol [12]. Following this hydrolysis, NEFA mobilizes into circulation and quickly attaches to serum albumin for transport to various tissues [129].

\section{Liver}

The liver has a key role in lipid metabolism and maintaining lipid homeostasis in animals $[89,112]$. Physiological, metabolic and endocrine adaptations that take place in the liver during early lactation support lipid metabolism in dairy cattle [89]. Many metabolic disorders affecting transition cows, such as fatty liver syndrome and ketosis occur as a result of increased lipid and fatty acid oxidation in the liver during this period of metabolic challenge $[33,47]$. The oxidation of long-chain fatty acids occurs in hepatic mitochondria and peroxisomes [33, 129]. Then triglycerides, the end product of liver $\beta$-oxidation, are carried by the lipoprotein very low density lipoprotein (VLDL). Lipoproteins are composed of triglycerides, cholesteryl esters, phospholipids and cholesterol [74]. Since cholesterol metabolism early in lactation has been a subject of intense investigation with regard to lipoprotein carriers, lipid metabolism-related disorders, membrane fluidity and steroid hormone synthesis [33, 74], this section will review pathways and genes that are involved in lipid metabolism as well as cholesterol and steroid hormone synthesis in the liver.

\section{Lipid Metabolism in the Liver}

NEFA generated through lipid metabolism can be oxidized by liver mitochondria or peroxisomes for use as an energy source or used by the mammary glands as a source of milk fat $[37,129]$. $\beta$-Oxidation occurring in the mitochondria involves production of acetyl-CoA, and reduction of nicotinamide adenine dinucleotide $\left(\mathrm{NAD}^{+}\right)$and flavin adenine dinucleotide $\left(\mathrm{FAD}^{+}\right)$in order to produce 


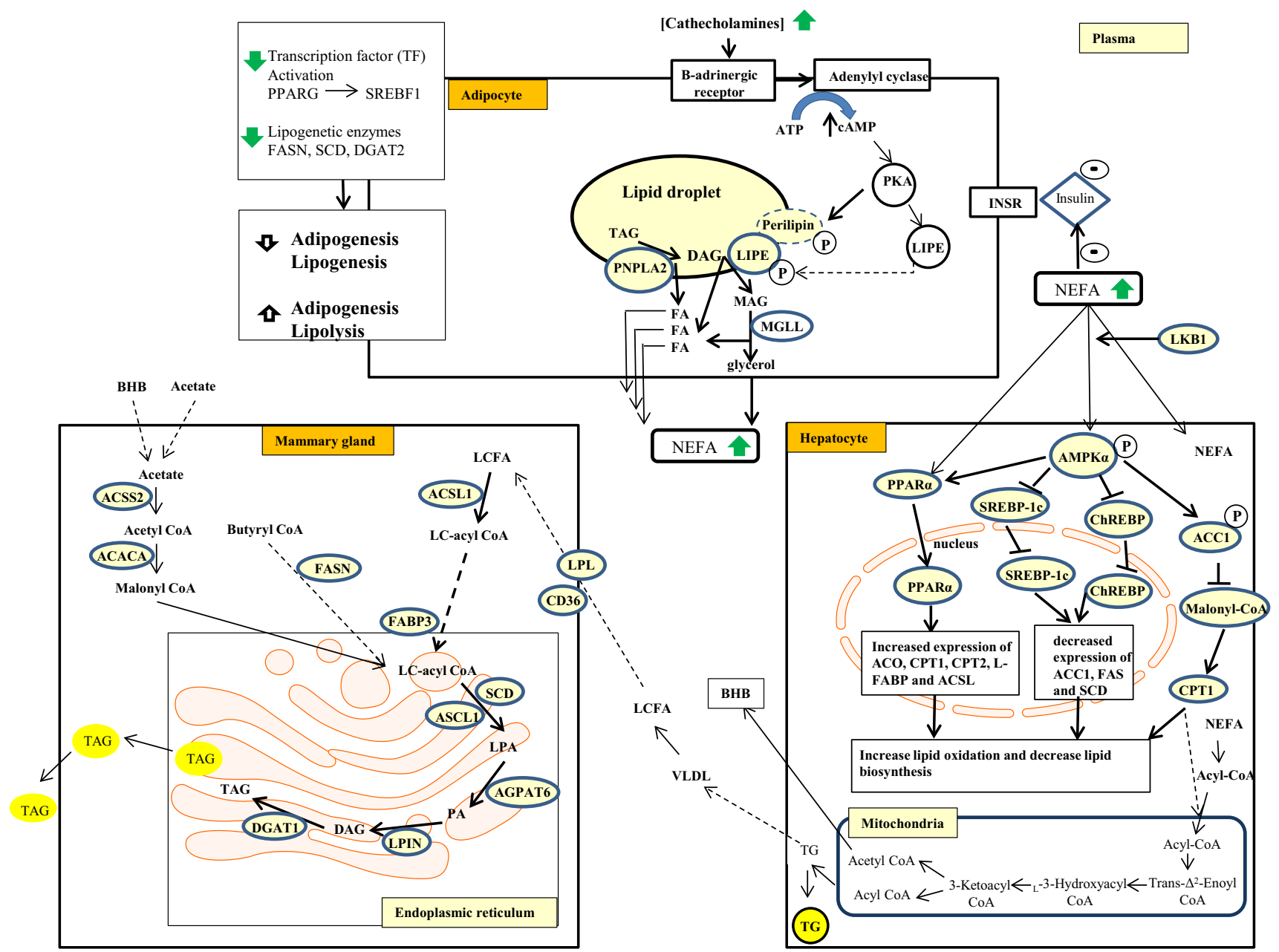

Fig. 1 Proposed steps, genes and pathways controlling energy metabolism in different tissues early in lactation. Solid/thick arrow lines denote processes that are activated. Solid non-arrow lines denote processes that are inhibited. Adapted from Refs. [14, 75, 88, 129]

adenosine triphosphate (ATP) in the citric acid cycle and electron transport chain. The alternative pathway of hepatic fatty acid oxidation is through peroxisomes.

\section{Oxidation of Fatty Acids in Mitochondria}

The $\beta$-oxidation of fatty acids in liver occurs mainly in the mitochondria. The carnitine palmitoyltransferase (CPT) system is recognized as a component of fuel homeostasis and transport system for these NEFA for $\beta$-oxidation [102]. This system is composed of three enzymes, carnitine palmitoyltransferase I (CPT-I), carnitine-acylcarnitine translocase and CPT-II [33, 102]. NEFA are delivered to the liver and converted to fatty acyl-CoA esters by acylCoA synthase. Then acyl-CoA is taken up by CPT-I on the outer mitochondrial membrane to be activated in the form of fatty acylcarnitine [12]. This step is believed to be the rate-limiting regulatory step in the metabolism of longchain fatty acids [102]. Then, fatty acylcarnitine permeates the inner membrane and by the enzyme CPT-II reforms fatty acyl-CoA [102]. The activated fatty acyl then enters the pathway of $\beta$-oxidization in the mitochondrial matrix by a recurring sequence of four reactions: oxidation by flavin adenine dinucleotide (FAD), hydration, oxidation by $\mathrm{NAD}^{+}$and thiolysis by CoA (Table 1) [12, 99]. The nicotinamide adenine dinucleotide hydrogen (NADH) and FADH produced during these reactions generate ATP in the citric acid cycle and electron transport chain, respectively [12]. When fatty acid mobilization increases in adipocytes, excessive acetyl-CoA generated from $\beta$-oxidation is converted into acetoacetate and BHBA (beta-hydroxybutyrate), which are ketone bodies [129]. Ketone bodies are an important energy-providing mechanism for vital organs such as the brain in early dairy cow's lactation [129]. The remaining free fatty acids will be re-esterified to triglycerides (TG) and exported as VLDL to the plasma (Fig. 1) [50, 74]. Van den Top et al. [150] and Kessler et al. [74] showed that plasma VLDL-cholesterol, LPL- 
Table 1 Major enzymes and their physiological function early in lactation in dairy cattle

\begin{tabular}{|c|c|c|c|}
\hline Enzyme name & Tissue & Function & Reference \\
\hline Acetyl-CoA carboxylase (ACC) & Adipocytes & $\begin{array}{l}\text { Lipogenesis (carboxylation of acetyl-CoA to } \\
\text { malonyl-CoA) }\end{array}$ & {$[5]$} \\
\hline Acyl-malonyl ACP condensing & Adipocytes & $\begin{array}{l}\text { Lipogenesis (condensation of acetyl-CoA to form } \\
\text { malonyl-CoA) }\end{array}$ & {$[5,42]$} \\
\hline Lipoprotein lipase (LPL) & Adipocytes & $\begin{array}{l}\text { Lipogenesis (hydrolization of plasma TAG to form } \\
\text { NEFA and monoacylglycerides) }\end{array}$ & {$[5,112]$} \\
\hline Thioesterase & Adipocytes & $\begin{array}{l}\text { Lipogenesis (Hydrolization of } \mathrm{C}_{16} \text {-acyl ACP to } \\
\text { palmitate) }\end{array}$ & {$[84]$} \\
\hline Hormone sensitive-lipase (HSL) & Adipocytes & $\begin{array}{l}\text { Lipolysis (hydrolysis of fatty acids at sn-1 and sn-3 } \\
\text { position) }\end{array}$ & {$[84]$} \\
\hline Monoacylglycerol lipase & Adipocytes & $\begin{array}{l}\text { Lipolysis (hydrolysis of the remaining fatty acid at } \\
\text { the sn-2 position to generates NEFA) }\end{array}$ & {$[12]$} \\
\hline Acyl-CoA synthase & Hepatocyte (cytoplasm) & Conversion of NEFA to fatty acyl-CoA & {$[12,102]$} \\
\hline Carnitine palmitoyltransferase I (CPT-I) & $\begin{array}{l}\text { Hepatocytes (outer } \\
\text { membrane mitochondria) }\end{array}$ & $\begin{array}{l}\text { Fatty acid } \beta \text {-oxidation (uptake and formation of } \\
\text { fatty acids to fatty acyl-CoA) }\end{array}$ & [12] \\
\hline Carnitine-acylcarnitine translocase & $\begin{array}{l}\text { Hepatocytes (inner } \\
\text { membrane of } \\
\text { mitochondria) }\end{array}$ & $\begin{array}{l}\text { Fatty acid } \beta \text {-oxidation (translocation of fatty acyl- } \\
\text { CoA into the mitochondria) }\end{array}$ & [12] \\
\hline Carnitine palmitoyltransferase II (CPT-II) & $\begin{array}{l}\text { Hepatocytes (inner } \\
\text { membrane of } \\
\text { mitochondria) }\end{array}$ & $\begin{array}{l}\text { Fatty acid } \beta \text {-oxidation (reforming acyl-CoA in } \\
\text { mitochondria matrix) }\end{array}$ & {$[12,102]$} \\
\hline Acyl-CoA dehydrogenase & $\begin{array}{l}\text { Hepatocytes (mitochondria } \\
\text { matrix) }\end{array}$ & $\begin{array}{l}\text { Fatty acid } \beta \text {-oxidation (Dehydrogenation of acyl- } \\
\text { CoA by FAD) }\end{array}$ & [99] \\
\hline Enoyl-CoA hydratase & $\begin{array}{l}\text { Hepatocytes (mitochondria } \\
\text { matrix) }\end{array}$ & $\begin{array}{l}\text { Fatty acid } \beta \text {-oxidation (Hydration of enoyl-CoA to } \\
\text { hydroxyacyl-CoA) }\end{array}$ & [99] \\
\hline 3-hydroxyacyl-CoA dehydrogenase & $\begin{array}{l}\text { Hepatocytes (mitochondria } \\
\text { matrix) }\end{array}$ & $\begin{array}{l}\text { Fatty acid } \beta \text {-oxidation (oxidation of } \beta \text { - } \\
\text { hydroxyacyl-CoA to } \beta \text {-ketoacyl-CoA by } \mathrm{NAD}^{+} \text {) }\end{array}$ & [99] \\
\hline B-Ketothiolase & $\begin{array}{l}\text { Hepatocytes (mitochondria } \\
\text { matrix) }\end{array}$ & $\begin{array}{l}\text { Fatty acid } \beta \text {-oxidation (thiolysis of } \beta \text {-ketoacyl- } \\
\text { CoA) }\end{array}$ & [99] \\
\hline $\begin{array}{l}\text { 3-Hydroxy-3-methylglutaryle-CoA } \\
\text { synthase }\end{array}$ & Liver & $\begin{array}{l}\text { Cholesterol synthesis (formation of 3-hydroxy-3- } \\
\text { methylglutaryl-CoA from acetyl-CoA and } \\
\text { acetoacetyl-CoA) }\end{array}$ & {$[61,156]$} \\
\hline $\begin{array}{l}\text { 3-Hydroxy-3-methylglutaryl-CoA } \\
\text { reductase }\end{array}$ & Liver & $\begin{array}{l}\text { Cholesterol synthesis (reduction of 3-hydroxy-3- } \\
\text { methylglutaryl-CoA to mevalonate) }\end{array}$ & {$[12,156]$} \\
\hline Squalene synthesis & $\begin{array}{l}\text { Liver (endoplasmic } \\
\text { reticulum) }\end{array}$ & $\begin{array}{l}\text { Cholesterol synthesis (reduction of two farnesyl } \\
\text { pyrophosphate to form squalene) }\end{array}$ & {$[12]$} \\
\hline Oxidosqualene cyclase & Liver & $\begin{array}{l}\text { Cholesterol synthesis (cyclizes of squalene to } \\
\text { lanosterol) }\end{array}$ & [12] \\
\hline $\begin{array}{l}\text { Glycerol-3-phosphate acyltransferase } \\
\text { (GPAT) }\end{array}$ & $\begin{array}{l}\text { Mammary gland } \\
\text { (endoplasmic reticulum } \\
\text { and/or mitochondria) }\end{array}$ & $\begin{array}{l}\text { TAG synthesis (acylation of glycerol-3-phosphate } \\
\text { to form lysophosphatidic acid (LPA)) }\end{array}$ & {$[45,147]$} \\
\hline $\begin{array}{l}\text { 1-Acylglycerol-3-phosphate } \\
\text { acyltransferase (AGPAT; also known as } \\
\text { LPA acyltransferase) }\end{array}$ & $\begin{array}{l}\text { Mammary gland } \\
\text { (endoplasmic reticulum } \\
\text { and/or mitochondria) }\end{array}$ & $\begin{array}{l}\text { TAG synthesis (transfer of an additional fatty acid } \\
\text { to LPA to form phosphatidate (PA)) }\end{array}$ & {$[147]$} \\
\hline Lipin & $\begin{array}{l}\text { Mammary gland } \\
\text { (endoplasmic reticulum) }\end{array}$ & $\begin{array}{l}\text { TAG synthesis (conversion of the phosphatidate to } \\
\text { diacylglycerol) }\end{array}$ & {$[126,147]$} \\
\hline Diacylglycerol acyltransferase (DGAT) & $\begin{array}{l}\text { Mammary gland } \\
\text { (endoplasmic reticulum) }\end{array}$ & TAG synthesis (acylation of DAG to TAG) & {$[14,136,147]$} \\
\hline $\begin{array}{l}\text { P450 side-chain cleavage enzyme } \\
\text { (P450scc, CYP11A1) }\end{array}$ & $\begin{array}{l}\text { Inner mitochondrial } \\
\text { membrane of steroidogenic } \\
\text { cells (ovary) }\end{array}$ & $\begin{array}{l}\text { Steroid hormone synthesis (Pregnenolone } \\
\text { synthesis) }\end{array}$ & {$[63,82]$} \\
\hline $\begin{array}{l}\Delta^{5} \text {-3ß-hydroxysteroid dehydrogenase } \\
\text { isomerase (3ßHSD) }\end{array}$ & $\begin{array}{l}\text { Steroidogenic cells } \\
\text { (granulosa cells) in ovary }\end{array}$ & $\begin{array}{l}\text { Steroid hormone synthesis (progesterone } \\
\text { synthesis) }\end{array}$ & {$[63,116]$} \\
\hline
\end{tabular}


Table 1 continued

\begin{tabular}{|c|c|c|c|}
\hline Enzyme name & Tissue & Function & Reference \\
\hline 17 $\alpha$-Hydroxypregnenolone & $\begin{array}{l}\text { Steroidogenic cells (theca } \\
\text { cells) ovary }\end{array}$ & $\begin{array}{l}\text { Synthesis of oestrogen and androstenedione from } \\
\text { progesterone }\end{array}$ & [116] \\
\hline $17 \beta$-Hydroxysteroid dehydrogenases & Ovary & Synthesis of testosterone from androstenedione & [116] \\
\hline CYP19A1 (aromatase) & $\begin{array}{l}\text { Theca-interstitial cells of } \\
\text { ovary }\end{array}$ & Testosterone & {$[63,82]$} \\
\hline
\end{tabular}

cholesterol (lipoprotein lipase) and TG concentrations decrease distinctively after parturition. Limited secretion of VLDL from liver and accumulation of TG in the liver can then lead to fatty liver syndrome [150].

\section{Oxidation of Fatty Acid in Peroxisomes}

The oxidative pathway of NEFA in peroxisomes is similar to that in mitochondria. However, one of the products of these reactions is hydrogen peroxide instead of NADH. In addition, peroxisomes do not contain a respiratory chain linked to ATP which results in the capture of less energy and more heat during peroxisomal $\beta$-oxidation [37]. Therefore, peroxisomal $\beta$-oxidation may be considered as an overflow pathway to oxidize fatty acids (FA) during extensive NEFA mobilization [37].

\section{Cholesterol and Steroid Hormone Metabolism}

The transition period not only requires homeorhetic changes in glucose and lipid metabolism but also cholesterol metabolism [5, 74]. Cholesterol is a fundamental lipid in modulating cell membrane fluidity and is the precursor of steroid hormones such as progesterone, testosterone, oestradiol and cortisol [12]. This section describes the biochemical pathways involved in cholesterol and steroid hormone synthesis, as well as regulatory components and interactions mediating cholesterol homeostasis in dairy cows during the transition period.

\section{Cholesterol Synthesis}

Cholesterol and fatty acids are synthesized in the liver [61]. Cholesterol has 27 carbon atoms in its structure, all of which are derived from acetyl-CoA. Synthesis of cholesterol starts with the formation of 3-hydroxy-3-methylglutaryl-CoA (HMG-CoA) from acetyl-CoA and acetoacetylCoA. This stage is mediated by 3-hydroxy-3-methylglutaryl-CoA synthase [156]. Then, HMG-CoA is reduced to mevalonate for the synthesis of cholesterol. The synthesis of mevalonate is the main step in cholesterol formation and is catalyzed by 3-hydroxy-3-methylglutaryl-CoA reductase (HMG-CoA reductase) [12, 156]. Mevalonate is converted into 3-isopentenyl pyrophosphate and this molecule condenses in three steps to form farnesyl pyrophosphate [12]. Then, two molecules of farnesyl pyrophosphate reduce to form squalene. This reaction is catalyzed by the endoplasmic reticulum enzyme, squalene synthase. Squalene is cyclized by oxidosqualene cyclase to form lanosterol (Table 1). The final stage of cholesterol synthesis is the conversion of lanosterol to cholesterol in a multistep process [12].

\section{Steroid Hormone Synthesis from Cholesterol}

Cholesterol is the building block for all of the five major classes of steroid hormones: progestogens, glucocorticoids, mineralocorticoids, androgens and oestrogens [12]. Steroid hormone synthesis is stimulated and controlled by different peptide hormones in different organs. For example, follicle-stimulating hormone (FSH) controls the progesterone and oestrogen synthesis in ovarian granulosa cells, whereas luteinizing hormone ( $\mathrm{LH})$ regulates progesterone synthesis in ovary luteinized granulosa-luteal cells, and androgen production in ovarian theca-interstitial cells [63]. Steroid hormones contain 21 carbon atoms. The first stage in the synthesis of steroid hormones is the removal of a six-carbon unit from cholesterol to form pregnenolone, a reaction catalyzed by the cytochrome $\mathrm{P} 450$ side-chain cleavage enzyme (P450scc, CYP11A1) on the inner mitochondrial membrane [63, 82]. Progesterone is then synthesized from pregnenolone in two steps: (1) oxidization of the 3-hydroxyl group of pregnenolone and (2) isomerization of the $\Delta^{5}$ double bond to a $\Delta^{4}$ double bond [12]. This step is catalyzed by the rate-limiting $\Delta^{5}-3 \beta$-hydroxysteroid dehydrogenase-isomerase (3$\beta$ HSD) enzyme in steroidogenic cells in the ovary $[63,116]$.

Androgens and oestrogens are synthesized from progesterone in two steps: (1) hydroxylation of progesterone at C-17 and (2) cleavage of the side chain consisting of C-20 and C-21 carbons to yield androstenedione which is an androgen. This reaction is catalyzed by the $17 \alpha-$ 
hydroxylase enzyme which uses $\Delta^{5}$ as substrate for the lyase activity [116]. Testosterone, which is secreted from theca-interstitial cells of the ovary, is another androgen and is formed by the reduction of the 17-keto group of androstenedione $[12,116]$. This reaction is catalyzed by 17 $\beta$-hydroxysteroid dehydrogenases [116]. The oestrogens, oestrone and oestradiol (E2), are synthesized from androgens by the loss of the C-19 methyl group [12]. Testosterone and androstenedione can be further metabolized to oestradiol and oestrone, respectively, in the ovary in a reaction catalyzed by the aromatase enzyme (CYP19A1) $[12,63]$. The ovarian granulosa cells secret progesterone (P4) and oestradiol, and ovarian theca cells predominantly synthesize androgens.

\section{Mammary Gland}

The mammary gland synthesizes and secretes a large number of products in the milk including proteins (whey $20 \%$ and casein $80 \%$ ), carbohydrates, coated lipid droplets, water and ions [8]. Milk fat is of major importance to the dairy industry, as it influences the manufacturing properties and other organoleptic qualities of milk and dairy products $[8,14]$. Several studies have defined and quantified major metabolic aspects of mammary lipid metabolism. These main lipid-associated metabolic pathways are the ones involved in fatty acid uptake from the blood (through endothelial long-chain fatty acid transport), de novo fatty acid (FA) synthesis (in cytosol), FA synthesis in the mitochondria and milk lipid synthesis, droplet formation and secretion (in the endoplasmic reticulum (ER) membrane) [7, 8, 14]. Fat production and milk FA composition are affected by the stage of lactation and level of production [13, 14, 71]. Transcriptional studies of the bovine mammary gland have highlighted a complex and coordinated set of molecular events that are involved in mammary adaptations to lactation $[14,85]$. This section will briefly review these molecular events from endothelial FA uptake to lipid droplet formation in the ER membrane.

\section{Blood Fatty Acid Uptake and De Novo Fatty Acid Synthesis}

The mammary gland can use two sources of fatty acids for milk fat synthesis. One source is the de novo synthesized fatty acids produced by mammary epithelial cells; the other source is fatty acids that are obtained from the digestive tract or through mobilization of body reservoirs [96]. Short chain (4-8 carbons), medium chain (10-14 carbons) and a portion of long-chain fatty acids (16 carbons) are synthesized from acetate and $\beta$-hydroxybutyrate in the de novo FA synthesis process; the remaining longchain fatty acids (including the other half of 16 carbon FA and all FA longer than 16 carbons) are taken up from circulation by the mammary gland [7]. In ruminants, fatty acids are derived predominantly from intestinal absorption of dietary and microbial fatty acids [7]. Early in lactation, however, when the animal is in negative energy balance, the contribution from mobilized fatty acids (such as circulating lipoproteins and NEFA) increases [6, 96]. Mammary cells take up albumin-bound FA (or NEFA) and lipoproteins. The VLDL or chylomicrons are also anchored to mammary endothelium by lipoprotein lipase (LPL) which hydrolyzes triacylglycerol (TAG) in the lipoprotein to release the FA [42]. Most of these longchain fatty acids (LCFA) are then esterified with CoA to LC-acyl-CoA (LCACoA) in the inner face of the plasma membrane before participating in metabolic pathways [14]. This step is regulated by the acyl-CoA synthetase long-chain family member 1 (ACSL1) gene which has been shown to be most predominant among other acyl-CoA synthetase mRNA isoforms in the bovine mammary tissue during lactation $[14,15]$. The ACSL1 gene converts free long-chain fatty acids into fatty acyl-CoA esters (Fig. 1). Specific localization of ACSLI gene product in the plasma membrane, endoplasmic reticulum and the mitochondriaassociated membrane supports channelling of LCFA and synthesis of TG from LCFAs [14, 15, 31].

\section{Triacylglycerol (TAG) Synthesis and Formation of Milk Lipid Droplets}

The activated long-chain fatty acids (LCACoA) bound to FABP3 (fatty acid-binding protein 3 ) gene protein are used as substrate for the SCD (stearoyl-CoA desaturase) enzyme, which is located on the ER membrane $[14,15]$. SCD adds a double bond to the $\Delta^{9}$ position of unsaturated fatty acids (myristoyl-, palmitoyl- and stearoyl-CoA) and triacylglycerol synthesis (TAG) begins through a series of sequential reactions carried out by the products of the GPAM (glycerol-3-phosphate acyltransferase), LPINI (Lipin I) and DGAT1 (diacylglycerol acyltransferase I) genes (Fig. 1) [15]. The first step in TAG synthesis is the acylation of glycerol-3-phosphate to form lysophosphatidic acid (LPA); this step is catalyzed by the glycerol-3-phosphate acyltransferase (GPAT) enzyme [45]. Then a fatty acid is transferred to LPA by LPA acyltransferase (also called AGPAT) enzyme to produce phosphatidate (PA) [147]. The PA is then served as a precursor of diacylglycerol (DAG). Lipin enzyme (an endoplasmic reticulum enzyme) catalyzes this reaction (Table 1) [126]. Finally, DAG converts to TAG by way of the diacylglycerol acyltransferase (DGAT) enzyme [136, 147]. The formed TAGs are enveloped by the ER plasma membrane and gradually move to the apical surface of the cell to the point that they dissociate from the cell [72]. The bovine milk 
lipid droplet is dependent on the adipose differentiationrelated protein (adipophilin, ADFP) for differentiation from the ER membrane and the product of the butyrophilin, subfamily I, member AI (BTN1Al) gene for differentiation from cell membrane [14, 72].

\section{Endocrine Adaptations in Transition Dairy Cows}

As a result of negative energy balance (NEB) early in lactation, major changes in hormonal regulation occur in high-yielding dairy cows [35]. This involves changes in the concentrations of key hormones as well as tissue responsiveness. For example, an increase in lipolysis and decrease in lipogenesis occur in order to maintain physiological equilibrium of the body and to satisfy the needs of the mammary gland through nutrient redistribution $[5,6,35,129]$. Blood hormone concentrations have an important role in mammary gland development and lactogenesis during the periparturient period [5]. Pituitary growth hormone $(\mathrm{GH})$, the thyroid gland hormones, insulin, catecholamines and leptin are some examples of the endocrine factors regulating lipid metabolism $[5,35,129]$.

The physiological effects of growth hormone are initiated when it binds to GH receptors (GHR) on target cells. Growth hormone enhances the lipolytic response of adipose tissue to $\beta$-adrenergic signals and is reported to have a positive effect on hormone-sensitive lipase (HSL) activity in adipose tissue [39, 129]. Binding of GH to its receptors (GHR-1A) in the liver initiates synthesis and secretion of insulin-like growth factor 1 (IGF-1) [129]. Despite the increase in plasma GH concentrations early in lactation, the abundance of hepatic GH receptors decreases, and as a result plasma IGF-1 also decreases [17, 95, 129]. Decreasing liver GHR abundance initiates lipolysis [129]. Since the concentration of IGF-1 does not fluctuate with feeding activity, it is a good indicator of nutritional status [148]. An optimum concentration of IGF-1 to maintain enough of a pool of circulating IGF-1 and its widespread actions is achieved by six binding proteins (IGFBPs 1-6) and the acid-labile subunit (ALS) [128, 148]. In addition, many members of the somatotropic axis (hypothalamo-pituitary axis) are expressed locally within endometrium [160]. For example, IGF-1 and IGF-2 act through type 1 IGF receptor (IGF1R) and are also expressed in the post-partum uterus [160]. IGFI and $I G F 2$ are expressed in many organs of the body and have an influence on proliferation, differentiation and metabolic activities. These genes may therefore play a role in uterine involution $[93,160]$.

Insulin has a regulatory effect on lipogenesis and is an antagonist to the lipolytic actions of GH [153]. Hypoinsulinemia (low concentrations of insulin in the blood) and a decrease in responsiveness of skeletal muscle and adipose tissue to insulin occurs simultaneously in early lactation and leads to an insulin-independent uptake of the available glucose by the mammary gland and greater body lipid mobilization to the liver $[11,129]$. This process begins with lower insulin concentration and elevated placental lactogen in the uterus during late pregnancy which stimulates adipose metabolism to provide nutrients for the growing foetus [138].

Leptin, secreted from adipocytes, decreases immediately post-partum as a consequence of energy deficit [87, 129]. This reduction in leptin production matches the plasma insulin profile early in lactation and is consistent with reduced adipose tissue glucose uptake [87, 129]. Leptin hormone secretion is regulated by a complex of different molecules and hormones such as insulin, glucocorticoids and cytokines (tumour necrosis factor (TNF) $\alpha$ ), interleukin-1 (IL-1), catecholamines, testosterone and PPAR $\gamma$ [153].

Catecholamines, such as epinephrine and norepinephrine, act as lipolytic stimulators through activating cAMP and then PKA which activates subunits of both HSL and perilipin proteins that subsequently increase lipolysis (Fig. 1) [12, 129]. Perilipin phosphorylation, which occurs through a cAMP-dependent PKA cascade, is essential for translocation of HSL hormone from cytosol to the surface of the lipid droplet [129]. It has been reported that the transcription of the genes producing perilipin, B-adrenergic receptors and HSL in adipose tissue increases early in lactation in dairy cows [145]. In addition, the responsiveness of bovine adipose tissue to catecholamines increases in early lactation [103].

Thyroid hormones have an important role in the dairy cattle transitional period and in determining cell metabolism intensity, metabolism of lipids and carbohydrates and lactation course in general [36]. These hormones are known for their importance in milk production through stimulation of metabolic rates with other hormones [19]. It has been shown that there is a positive correlation between thyroid hormones in blood and energy metabolism [124]. During negative energy balance and high lipid metabolism, however, the concentrations of $\mathrm{T} 4$ (thyroxine) and $\mathrm{T} 3$ (triiodothyronine which is four times more active than T4) are reduced (hypothyroidism) in the blood of dairy cows shortly before and after calving [19, 118, 124]. Negative energy balance and an increase in lipid mobilization and hypothyroidism early in lactation in dairy cows are accompanied by metabolic disorders associated with carbohydrate and lipid metabolism such as ketosis and fatty liver [35]. Therefore, thyroid hormones are considered to be important indicators of homeorhetic adaptation to negative energy balance in dairy cows until energy balance is achieved [35, 36, 69]. 


\section{Reproductive Endocrinology and Hormonal Adaptations in Cows in Negative Energy Balance (NEB) Stage}

Reproductive function in dairy cattle is dependent on balanced and coordinated endocrine activity [160]. This includes homeostasis between different reproduction hormones such as gonadotrophin-releasing hormones $(\mathrm{GnRH})$, follicle-stimulating hormone (FSH), luteinizing hormone (LH), prolactin (PRL) and gonadal steroids as well as prostaglandin F2-alpha $\left(\mathrm{PGF}_{2 \alpha}\right)$ from the uterus [86]. Shortly before parturition, $\mathrm{PGF}_{2 \alpha}$ increases and luteolysis of corpus luteum (CL) begins. Progesterone decreases rapidly as a result of CL regression. Plasma oestrogen concentration drops immediately after calving to the values below those found during the normal oestrous cycle [66].

It has been shown that NEB is a reason for poor conception rates in transition dairy cows [41, 161, 162]. The relationship between NEB and fertility stems from the effects of NEB on the resumption of cyclicity and on the quality of oocyte or the corpus luteum which is discussed below.

Ovarian cyclicity and ovulation after calving are necessary for a successful insemination and cows should be able to ovulate approximately 2-3 months post-partum [66]. Gonadotropins play an important role in the onset of this activity. FSH concentrations remain at relatively constant levels throughout the post-pubertal life of a dairy cow, but LH concentrations become pulsatile in cyclic animals [86]. Inhibition of LH pulsatility before puberty leads to decreased ovarian activity [66]. Besides, the onset of puberty has been shown to be associated with the attainment of a critical level of body fat [66, 134]. Therefore, it has been suggested that there is a relationship between the metabolic status of the animal and reproductive endocrine system of dairy cow not only for the onset of puberty in heifers, but also for resumption of ovarian activity in non-adoptive dairy cows early in lactation [134]. In this regard, LH seems to have a more important role than FSH after calving [142]. Low glucose concentrations have also been associated with less amplitude of LH pulses. In addition, endogenous opioid peptides, which are secreted during stress, have negative effects on LH pulsatility and the onset of ovarian activity post-partum $[1,66]$.

The IGF-1 system is thought to influence the establishment and maintenance of pregnancy of dairy cows through affecting reproductive tract of cows [148]. The IGF-1 protein acts as a co-gonadotroph and amplifies the effects of FSH and LH on the growth and differentiation of ovarian follicles [95, 148]. The IGF-1 system also plays an important role in the survival of the embryo and its plasma concentrations were shown to be associated with longer calving to conception intervals [148, 162]. It has been reported that regulation of $I G F 1$ and $I G F 2$ is in positive manner with ovarian oestradiol production [41, 66, 143]. The concentration of IGF-1 increases notably at a time of increasing oestradiol dominance in the bovine oviduct [143]. Moreover, IGF-1 and insulin have a stimulatory effect on ovarian granulosa cells, increasing proliferation, as well as progesterone and oestradiol production. Insulin and IGF-1 also stimulate androgen production in (ovarian) theca cells $[66,141]$. Recent studies have further suggested the role of thyroid hormones in the onset of ovarian activity $[66,150]$.

The quality of oocytes at the time of insemination is important in non-adopting dairy cows and is dependent on the sufficient number of ovarian cycles and the time that an antral follicle needs to reach its ovulatory size after calving [66]. Several factors and hormones can affect the quality of oocytes. IGF-1 and its binding proteins might affect the quality of oocytes. Follicular development can be inhibited with increased IGFBPs that are known to function as IGF-1 inhibitors [66]. The second is the metabolic status of the dairy cow. As a result of an increase in body fat mobilization and to some extent body protein mobilization, plasma urea concentrations increase early in lactation [66]. The increase in ammonia concentrations may also occur as a result of accumulation of triacylglycerides and inhibition of ureagenesis during the transition period in dairy cows [169]. A high concentration of circulating urea and ammonia in the bloodstream of cows is associated with reduced fertility [83, 128, 160]. Exposure of oocytes in antral follicles to high levels of ammonia concentrations during fertilization may hamper cleavage and blastocyst formation [137]. Increased urea concentration in the blood early in lactation is associated with declined cleavage ratios and blastocyst formation of the fertilized embryo [66, 160]. This increased level of urea concentration in the blood after calving may also influence the expression of endometrial IGF and insulin receptor (INSR) [160]. Wathes et al. [160] reported that expression of IGFIR and INSR was not altered by the energy balance status of the dairy cow early in lactation but was positively correlated with the circulating urea concentration [160].

\section{Regulatory Components and Genes Mediating Metabolic and Endocrine Adaptations}

Differences in the success of adaptation early in lactation between cows, under the same conditions and similar production level, suggest that adaptability may have a genetic basis [53, 74, 151]. Many genes, pathways and key candidate metabolites in the plasma have been previously confirmed to be essentially involved in the regulation of metabolic and endocrine adaptations in dairy cow $[15,33,53,160]$. However, these genes and pathways 
might be expressed only at a certain point of time in the individual [53]. Some genes, for example those affecting glucose levels, might be expressed in early lactation and others, affecting the abundance of non-esterified fatty acids (NEFA) for example, are expressed 4 weeks before or 13 weeks after calving [53]. Identifying the genes and pathways regulating important biological functions during specific physiological states of dairy cattle may help in the identification of DNA variants that affect milk production and subsequent fertility [139].

\section{Genes and Key Pathways Affecting Multiple Tissues}

The onset of lactation in dairy cows is accompanied by an increase in milk synthesis and nutrient requirements, and eventually there is metabolism adaptation to lactation-associated challenges. These adaptations include metabolism adjustments in liver and peripheral tissues (including adipose tissue, mammary gland, skeletal muscle tissues and kidney), and mobilization of body reserves and increased lipid metabolism [163]. The increase in lipid metabolism results in an increase in concentrations of key metabolites NEFA and BHBA in plasma (Fig. 1), and TAG in liver $[129,135]$. Several genes and pathways in multiple tissues are involved in regulating these metabolites in lactating dairy cows $[14,15,23,53,90,98,135]$. A gene-based mapping and pathway analysis indicated that three pathways (steroid hormone biosynthesis, ether lipid metabolism and glycerophospholipid metabolism) jointly affect the concentrations of NEFA, BHBA and glucose in cows during the transition period [53]. The key genes that are involved in regulating energy metabolism in multiple tissues include PPRA, PCK1, PCK, ACACA, FASN, FBP2, FABP3, PPARGC1A, ACSL1, PPARGCIA, AGPAT6, PCCA, LPINI, ACO, CPT-I, CPT-II and ACSL $[4,15,27,94,131,163]$. These genes are involved in fatty acid uptake (mainly in the liver and mammary gland), mitochondrial and peroxisomal fatty acid oxidation, ketone body metabolism (ketogenesis) and cholesterol metabolism (in liver) early in lactation in dairy cattle [135] and are discussed in the following tissue-specific sections in more detail.

Gene expression studies are revealing the extent to which different genes are involved in different tissues $[4,135,163,167]$. For example, genes that are involved in carbohydrate metabolism, such as those encoding gluconeogenesis and propionate metabolism enzymes (including $P C K 1$ ), were expressed more in liver than mammary tissues $[4,167]$. However, the related $P C K 2$ gene shows a small difference in expression between mammary gland and liver [4, 163, 167]. Other studies showed that the PCK2 gene might also be active in glyceroneogenesis in lipogenic tissues (adipose tissues) during fasting or restricted feed intake [54, 125] and in the epithelial cells of mammary tissue during lactation [62]. Weikard et al. [163] reported that expression of the PPARGC1A gene was significantly increased in liver, mammary gland and skeletal muscle in lactating cows. The PPARGCIA gene coordinates expression of several proteins and in this way it controls the regulation of several metabolic pathways in response to metabolic challenges [163]. This gene has been reported to have a pivotal role in hepatic glucose synthesis (gluconeogenesis) [121], to be a key gene in mitochondrial oxidative phosphorylation metabolism [109, 115], and to independently regulate the expression of several lipogenic genes after the onset of lactation in dairy cattle [14]. In a study comparing gene expression patterns between liver, mammary gland and skeletal muscle tissues in lactating cows, Weikard et al. [163] indicated that the PPARGC1A and PCCA genes display a significantly altered mRNA abundance between the tissues and across all the cow groups under investigation: cows with different genetic potential for milk performance (high milk performance, medium and low milk performance) and cows with different genetic backgrounds (purebred and combined beef, dairy background). Fatty acid-binding proteins (FABP) are the main transporters of long-chain fatty acids (LCFA) to specific organelles for metabolism [101]. Different isoforms of FABPs have shown unique patterns of tissuespecific gene expression [43] and are most abundant in tissues that are involved in active lipid metabolism [4]. In this regard, FABP3 was shown to have a major role in bovine mammary gland lipid synthesis and is much more abundant in this tissue $[4,14]$. FABP1 was shown to be more abundant in liver [27], whereas expression of FABP4 was reported to be greater in mammary and adipose tissues $[4,64]$. There are nine isoforms of 1-acylglycerol-3-phosphate $O$-acyltransferase (AGPAT) in mammals, an enzyme that catalyzes the transfer of fatty acyl-CoA to lysophosphatidic acid [166]. The AGPAT1 isoform is the most abundant one in both liver and mammary tissues [4], but a knockout study in mice suggests an important role for AGPAT6 as well in mammary tissues, in the biosynthesis of milk fat [9].

\section{Genes and Key Pathways Regulating Liver Lipid and Cholesterol Metabolism in Transition Dairy Cow}

NEFA, beta-hydroxybutyrate (BHBA) and glucose are key factors in the metabolic status of transition dairy cows [48, 53, 151]. Ha et al. [53] reported that several pathways jointly regulate concentrations of these metabolites, including three highly significant pathways: steroid hormone biosynthesis, ether lipid metabolism and glycerophospholipid metabolism. Several genes are associated 
with these pathways including $C D 53, A B C C 1$, ADCYAP1R1, ZNF551, AHCYL1, WWC1 and MED19 [53]. $\mathrm{Ha}$ et al. [53] also reported similar links to pathways and genes associated with cholesterol metabolism and NEFA concentrations in dairy cows. These results are in agreement with Kessler et al. [74] who showed that mRNA abundance of genes involved in cholesterol synthesis (SREBF2, HMGCS1 and HMGCR and ABCG1) markedly increased early in lactation [61, 74].

The high concentration of NEFAs early in lactation can act as signalling molecule, regulating the expression of hepatocyte genes that are involved in lipid metabolism $[38,67,88]$. In this regard, AMP-activated protein kinase (AMPK) signalling pathways have been shown to be a key regulator of hepatic lipid metabolism, responding to hormones and metabolites including NEFAs [88]. AMPK acts as a mediator for expression of transcriptional factors, peroxisome proliferator-activated receptor $\alpha$ (PPAR $\alpha$ ), sterol regulatory element-binding protein-1c (SREBP-1c) and carbohydrate-responsive element-binding protein (ChREBP) [88, 155]. Activation of these transcriptional factors leads to the expression of lipolytic and lipogenic genes $[70,88,168]$. Activated PPRA $\alpha$ can increase expression of lipolytic genes (ACO, CPT-I, CPT-II, L$F A B P$ and $A C S L$ ) and subsequently lipid oxidation [88]. This is while AMPK $\alpha$ inhibits transcription factors (SREBP-1c and ChREBP) which decrease expression of lipogenic genes (ACC1, FAS and SCD-1) and eventually lipid synthesis (Fig. 1) [88]. In addition, CPT-I activity increases by activated AMPK $\alpha$; activated CPT-I increases downstream hepatic enzymatic activity and lipid metabolism [88].

One of the important genes that control synthesis of sterols is SREBF2 [61]. Kessler et al. [74] showed that there is a significant correlation between SREBF2 mRNA expression and the hepatic gene expression of both 3-hydroxy-3-methylglutaryl-CoA reductase (HMGCR) and $H M G C S 1$. In addition, several investigations showed that occurrence of fatty liver syndrome early in lactation is associated with cholesterol carrier lipoproteins such as VLDL $[50,74]$. Cholesterol is transported by high density lipoproteins (HDL) from peripheral tissues to the liver [74]. The ABCAl gene regulates formation of HDL. Furthermore, Viturro et al. [156] reported a maximum increase in the expression levels of two transcription regulatory proteins, SREBP1 and SREBP2, on the week 2 post-partum that was coordinately and significantly correlated with an increase in the expression levels of the enzyme 3-hydroxy3-methylglutaryl-CoA reductase (HMGCR) and 3-hydroxy-3-methylglutaryl-CoA synthesis [156]. These results indicate that there are complex regulatory mechanisms involved in the homeostasis of cholesterol in transition dairy cows.
Genes and Key Pathways Regulating Milk Fat Synthesis in Mammary Gland in Transition Dairy Cow

Early in lactation, fatty acid (FA) uptake from blood predominates relative to de novo FA synthesis in the mammary gland [14]. This change in milk FA synthesis is mediated by up-regulation of genes and pathways that are associated with FA uptake from blood (such as $L P L$, $C D 36$ ) and intracellular transport/channelling genes (such as $F A B P 3$ ) [14]. Moreover, early in lactation, significant up-regulation of other genes and pathways has been observed, such as up-regulation of genes responsible in the activation of fatty acids (e.g. ACSL1, ACSS2), de novo FA synthesis (e.g. ACACA, FASN), FA desaturation (e.g. SCD, $F A D S 1$ ), synthesis of TAG (e.g. AGPAT6, GPAM), lipid droplet formation (e.g. BTNAI) and ketone body utilization (e.g. BDH1, OXCT1) [14]. Bionaz and Loor [14] also suggested that expression of SREBFl is central to milk fatty acid synthesis and that the genes PPARG, LASS2, INSIG1 and OSBP have a pivotal role in regulating lipid synthesis and mammary intracellular equilibrium between cholesterol and sphingolipids in lactating dairy cows.

\section{Genes and Key Pathways Regulating Lipid Metabolism in Adipose Tissue in Transition Dairy Cow}

With increasing milk production and onset of a period of negative energy balance, the expression of many genes and enzymes controlling lipid metabolism in adipose tissue changes [75, 88]. These changes favour a decrease in lipogenesis and an increase in lipolysis. Khan et al. [75] reported a decrease in the expression of genes controlling adipogenesis including PCK1, FASN, SCD, DGAT2, PPRAG, WNTIOB and SREBF1. These results are in agreement with previous work by Sumner and McNamara [145] and Bionaz and Loor [16] which reported that adipose lipogenesis in cows during early lactation is primarily regulated through control of gene expression. Expression of key lipolytic enzyme genes (LIPE, PNPLA2, MGLL and $A D R B 2$ ) followed a similar pattern early in lactation, indicating that the control of lipolysis in the adipose tissue is likely controlled by post-transcriptional events [75, 104, 153]. Post-transcriptional activation of HSL through simulation of the $\beta$-2-adrenergic receptor and the phosphorylation cascade has been shown to be the first step in the beginning of lipolysis and providing fatty acids to the mammary gland and other tissues [75, 144]. The transcription of other lipolysis genes (LIPE, PLIN1 and $A D R B 2$ ) increases following an increase in the enzymatic capacity for continued supply of FA to other organs and rebuilding adipose stores [103]. Adipose triglyceride lipase 
(PNPLA2) has been reported to be a highly expressed lipolytic enzyme in the white adipose tissue of dairy cattle, which is associated with basal and $\beta$-2-adrenergic-simulated triacylglycerol hydrolysis [108].

\section{Influence of Energy Balance and Metabolites Early in Lactation on Gene Expression in the Endometrium of Post-partum Dairy Cow}

It has been reported that severe negative energy balance (SNEB) in high-producing post-partum dairy cows is associated with subsequent low fertility [160]. Excessive lipid metabolism, increased concentrations of NEFAs and $\mathrm{BHB}$ and reduced concentrations of glucose and IGF-1 are associated with reproductive disorders and poor conception rates $[7,161]$. The failure of multiparous cows to conceive is correlated with low IGF-1 circulation in the first 2 weeks post-partum [148, 160]. It has been shown that expression of IGF-binding protein 4 (IGFBP4) and inflammatory response genes including matrix metalloproteinases (MMP1, MMP3, MMP9 and MMP13), chemokines, cytokines and calgranulins significantly increase in the endometrium as a result of metritis in cows with SNEB [159, 160]. Wathes et al. [160] also reported that the expression of hormone receptors in the endometrium (IGF1R, IGF2R, INSR, GHR, NR3C1, ESR1 and ESR2) did not change according to the energy balance status and that there is a coordinated expression between hormone receptors $I G F 1 R, I G F 2 R$ and $I N S R$ as well as $G H R$ with ESR1 and NR3C1 with ESR2 [160]. Furthermore, increased concentrations of blood urea as a result of dietary factors and tissue protein catabolism may influence the expressions of endometrial IGF and INSRs [160].

\section{Candidate Genes Identified in the Key Tissues Through Association Analysis for Production and Fertility Traits}

The availability of highly informative marker maps, genome-wide association analysis [34], gene-based mapping (an association approach that tests each gene instead of each SNP separately as described in [53]) and pathway analysis [53] have resulted in the identification of several crucial regulated target genes and metabolic pathways in the mammary gland, liver and blood plasma that are responsible for the regulation of the metabolism early in lactation. For example, a QTL with a major effect on milk yield and composition has been identified on the centromeric end of the chromosome 14, and involves the DGATl gene [49]. Figure 2 shows a strong association of SNPs with milk production on chromosome 14 close to the $D G A T 1$ gene in a genome-wide association study done on Canadian Holstein dairy cattle [111]. Similarly, linkage disequilibrium (LD) analysis highlighted a chromosomal region on bovine chromosome 20 harbouring the $G H R$ gene which affects milk yield and composition [2, 18, 44]. Another association analysis revealed highly significant SNPs (false discovery rate at $P$ value $\leq 10^{-8}$ ) associated with fat and protein percentage on chromosome 19 residing within ACLY, which is a fatty acid biosynthesis gene [123]. Significant associations involving markers within or close to other fat metabolism associated genes such as FASN, SREBPBI and STAST5A have also been reported for milk production traits in dairy cattle [20]. In a recent study of a German Holstein-Friesian population, two highly significant polymorphisms were found to be associated with milk fat content; one of these variants is located within the promoter region of the EPS 8 gene on chromosome 5 and the other variant is located near the GPAT4 gene on chromosome 27 [158].

The product of the EPS 8 gene provides a substrate for receptor tyrosine kinases and physically interacts with the epidermal growth factor receptor (EGFR) [40]. Interaction of the EPS8 gene product with EGFR increases the signalling response to epidermal growth factor (EGF) [123]. The promoter SNP reported by [158] in EPS8 may mediate the binding of transcription factor TFAP2A to influence the transcription rate of EPS8. The expression of TFAP $2 A$ is correlated with the concentration of NEFA and liver triacylglycerol [158]. It has been demonstrated that sterol regulatory element-binding proteins (SREBPs), which control the expression of genes required for the uptake and synthesis of cholesterol, fatty acid and triglycerides, are regulated by the epidermal growth factors [26]. Therefore, it is plausible that an increased milk fat biosynthesis in the lactating mammary gland is the result of an enhanced transcription rate of EPS8, conferred by the binding of TFAP2A. The GPAT4 gene is near a QTL region reported to contribute to the genetic variation of milk fatty acid composition in the Dutch Holstein population [20, 158]. This gene plays an important role in lipid biosynthesis in mammals. The transcription rate of GPAT4 is highly correlated with concentrations of diacylglycerols and triacylglycerols in milk [9, 15]. In a more recent study, this region on chromosome 27 was reported for associations with milk fat and milk volume, protein and lactose content in Holstein and Jersey crossbreds [92]. Mullen et al. [110] have detected several novel and previously identified associations involving variants within introns of the IGF 1 gene associated with milk protein yield, milk fat yield, milk fat concentration, somatic cell score and carcass associated traits in Holstein dairy cattle [110]. The IGF-1 protein stimulates protein synthesis in the epithelial cells of the mammary gland and plays an important role in mammary gland growth and function [22]. A more comprehensive 


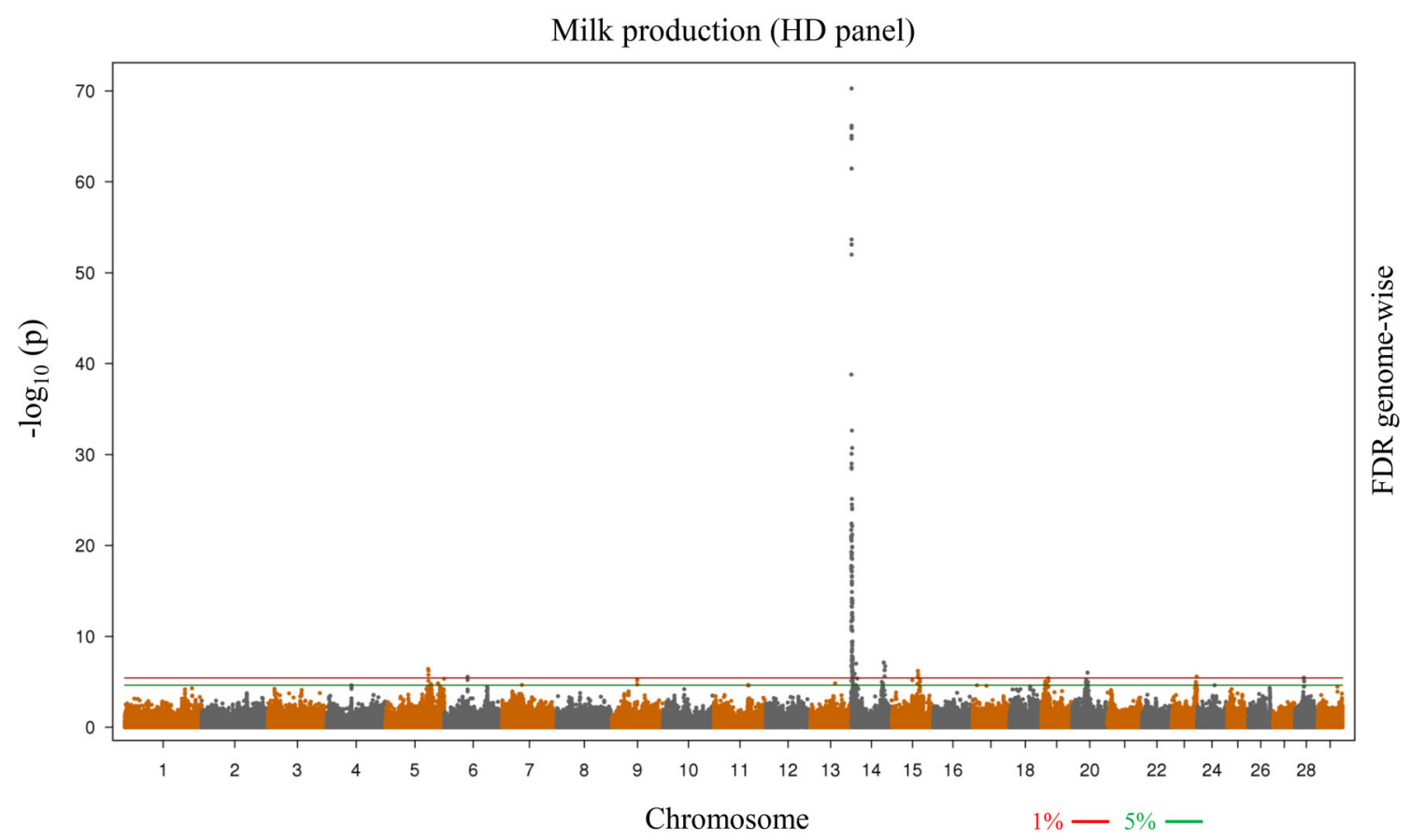

Fig. 2 Genome-wide association analysis of milk production in Canadian dairy Holstein cattle. The $-\log _{10}$ of the $P$-value for association with SNPs is plotted. Chromosome number is shown on

list of major candidate genes associated with milk production traits is shown in Table 2.

The impact of poor fertility in the dairy industry has led to the inclusion of a female fertility index in some breeding programs and has undoubtedly contributed to interest in identifying the loci affecting fertility [56-59]. Association and QTL mapping studies have identified several candidate genes affecting fertility traits including interval from calving to first insemination, days from first to last insemination, 56-day non-return rate and insemination per conception. For example, an investigation of QTL regions affecting female fertility traits in Nordic Holstein cattle identified a strongly associated missense mutation within the multifunctional CD36 gene on chromosome 4 [59]. In two other association studies in Nordic Red dairy cattle using $50 \mathrm{~K}$ SNP genotypes imputed into whole-genome sequencing data, several other genes including SLC6A17, SDS5, ADCY1, SLC1A4 and PPMIB associated with cow and heifer non-return rate, calving to first service interval, number of inseminations per conception and days from first to last insemination were identified $[57,60]$. The $T G F B 2$, $A P O H$ and IGLLI genes were reported as important candidate genes under significant peaks associated with nonreturn rate and days to first service in Italian Holstein cattle [107]. The genes TGFB2 and $A P O H$ are both involved in the process of the follicular development as they interact with the reproductive hormones LH and FSH [107]. The $T G F B$ isoforms can stimulate $\mathrm{FSH}$ receptor expression and the horizontal axis. The red line is the threshold for significant SNPs at $1 \%$ FDR. The green line is the threshold for significant SNPs at 5\% FDR. Adapted from Ref. [111]

amplify progesterone production and $\mathrm{LH}$ receptor induction [78]. The IGLL1 gene has also been reported to be upregulated during the peripartum period in the endometrium of the lactating dairy cow and may play an important role in energy balance by influencing production and fertility traits at the same time [24]. A list of major candidate genes identified through association studies for fertility-associated traits is provided in Table 3 .

\section{Genomic Regions and Genes Affecting Multiple Traits in Dairy Cattle}

Milk production and fertility traits are polygenic, affected by many genes and variants, each with a small effect on the observed phenotype $[111,139]$. GWAS studies of different production and fertility traits in dairy cattle have identified shared quantitative regions and candidate genes-regions that appear to influence multiple traits $[27,56,111,127]$. In some cases the effects are confined to multiple production traits. For example, the underlying genomic region on chromosome 14 that includes DGATl gene has been shown to have a major effect on milk fat content and several other production traits including milk yield, fat percentage and protein percentage [3, 100, 105, 111, 119, 165]. Similarly, several studies have reported associations of SNPs on chromosome 20 surrounding the GHR gene with milk yield, protein yield and protein percentage $[18,25,105,111,123,154]$. More recently, variants close 
Table 2 List of major candidate genes identified through association studies for production traits in dairy cattle

\begin{tabular}{|c|c|c|c|c|c|}
\hline Gene & Gene name & Chromosome & PUBMED-ID & Trait & Year \\
\hline POU1F1 & POU class 1 homeobox 1 & 1 & 18557974 & Milk yield, productive life & 2008 \\
\hline$D I P 2 A$ & $\begin{array}{l}\text { DIP2 disco-interacting } \\
\text { protein } 2 \text { homolog } \mathrm{A}\end{array}$ & 1 & 21048968 & Protein yield & 2010 \\
\hline TNFSF10 & Tumour necrosis factor & 1 & 21198698 & $\begin{array}{l}\text { Fat yield, protein yield, fat percentage, } \\
\text { interval from first to successful } \\
\text { insemination (cow) }\end{array}$ & 2011 \\
\hline MIS18A & $\begin{array}{l}\text { MIS18 kinetochore protein } \\
\text { homolog A (S. pombe) }\end{array}$ & 1 & 24456127 & Somatic cell score & 2014 \\
\hline SLC37A1 & $\begin{array}{l}\text { Solute carrier family } 37 \\
\text { member } 1\end{array}$ & 1 & 26613780 & Milk production & 2016 \\
\hline STAT1 & $\begin{array}{l}\text { Signal transducer and } \\
\text { activator of transcription } 1\end{array}$ & 2 & 17033032 & Milk yield, fat yield, protein yield & 2006 \\
\hline$C Y P 27 A 1$ & $\begin{array}{l}\text { Cytochrome } \mathrm{P} 450 \text {, family } 27 \text {, } \\
\text { subfamily A, polypeptide } 1\end{array}$ & 2 & 21198698 & Milk yield, somatic cell score & 2011 \\
\hline IFIHI & $\begin{array}{l}\text { Interferon induced with } \\
\text { helicase } \mathrm{C} \text { domain } 1\end{array}$ & 2 & 21198698 & Milk yield, fat yield, fat percentage & 2011 \\
\hline$I G F B P 2$ & $\begin{array}{l}\text { Insulin-like growth factor- } \\
\text { binding protein } 2,36 \mathrm{kDa}\end{array}$ & 2 & 21198698 & Lactation, establishment of pregnancy & 2011 \\
\hline SLC4OA1 & Solute carrier family 40 & 2 & 25148050 & Milk yield & 2014 \\
\hline$S P 110$ & SP110 nuclear body protein & 2 & 24456127 & Fat percentage & 2014 \\
\hline$S D C 3$ & Syndecan 3 & 2 & 24456127 & Mammary system & 2014 \\
\hline SMARCAL1 & $\begin{array}{l}\text { SWI/SNF-related, matrix } \\
\text { assoc., actin dep. Reg. of } \\
\text { chromatin, subfamily a-like } 1\end{array}$ & 2 & 24456127 & Mammary system & 2014 \\
\hline$G B A$ & Glucosidase beta, acid & 3 & 24456127 & Protein percentage & 2014 \\
\hline$C T T N B P 2 N L$ & CTTNBP2 N-terminal like & 3 & 24456127 & Somatic cell score & 2014 \\
\hline$M U C 1$ & $\begin{array}{l}\text { Mucin } 1 \text {, cell surface } \\
\text { associated }\end{array}$ & 3 & 26613780 & Milk production & 2016 \\
\hline$L E P$ & Leptin & 4 & $\begin{array}{l}15905454 \\
18565947 \\
18650297 \\
15927775\end{array}$ & $\begin{array}{l}\text { Milk protein, milk fat, lactation performance, } \\
\text { health, daily milk reproduction, postpartum } \\
\text { luteal activity }\end{array}$ & $\begin{array}{l}2005, \\
2008\end{array}$ \\
\hline OLR1 & $\begin{array}{l}\text { Oxidized low density } \\
\text { lipoprotein }\end{array}$ & 5 & 16606746 & Milk fat yield, milk fat percentage & 2006 \\
\hline GABARAPL1 & $\begin{array}{l}\text { GABA type-A receptor- } \\
\text { associated protein-like } 1\end{array}$ & 5 & 21198698,27287773 & Milk yield, fat percentage, fat production & $\begin{array}{l}2011, \\
2016\end{array}$ \\
\hline$M G P$ & Matrix Gla protein & 5 & 21198698 & Milk yield, fat percentage & 2011 \\
\hline EPS8 & $\begin{array}{l}\text { Epidermal growth factor } \\
\text { receptor pathway substrate } \\
8\end{array}$ & 5 & 24456127 & Milk yield & 2014 \\
\hline$M G S T 1$ & $\begin{array}{l}\text { Microsomal glutathione } \\
\text { S-transferase } 1\end{array}$ & 5 & 24456127 & Fat yield, fat percentage & 2014 \\
\hline$R P A P 3$ & $\begin{array}{l}\text { RNA polymerase II } \\
\text { associated protein } 3\end{array}$ & 5 & 24456127 & Milk yield, protein percentage & 2014 \\
\hline SOCS2 & $\begin{array}{l}\text { Suppressor of cytokine } \\
\text { signalling } 2\end{array}$ & 5 & 24779965 & $\begin{array}{l}\text { Mammary development pathways, prolactin } \\
\text { signalling pathways, lactation }\end{array}$ & 2014 \\
\hline ATF4 & $\begin{array}{l}\text { Activating transcription factor } \\
4\end{array}$ & 5 & 24779965 & Lactation yields, involution pathways & 2014 \\
\hline$C C D C 91$ & $\begin{array}{l}\text { Coiled-coil domain- } \\
\text { containing } 91\end{array}$ & 5 & 25148050 & Fat percentage & 2014 \\
\hline ITPR2 & $\begin{array}{l}\text { Inositol } 1,4,5 \text {-triphosphate } \\
\text { receptor, type } 2\end{array}$ & 5 & 25148050 & Fat percentage & 2014 \\
\hline ACSS3 & $\begin{array}{l}\text { Acyl-CoA synthetase short- } \\
\text { chain family member } 3\end{array}$ & 5 & 25511820 & Milk fat composition, milk fat percentage & 2014 \\
\hline
\end{tabular}


Table 2 continued

\begin{tabular}{|c|c|c|c|c|c|}
\hline Gene & Gene name & Chromosome & PUBMED-ID & Trait & Year \\
\hline$M K L 1$ & $\begin{array}{l}\text { Megakaryoblastic leukaemia } \\
\text { (translocation) } 1\end{array}$ & 5 & 27006194 & Milk yield & 2016 \\
\hline$V D R$ & $\begin{array}{l}\text { Vitamin } \mathrm{D}(1,25- \\
\text { dihydroxyvitamin } \mathrm{D} 3) \\
\text { receptor }\end{array}$ & 5 & 26613780 & Milk production & 2016 \\
\hline$C S F 2 R B$ & $\begin{array}{l}\text { Colony-stimulating factor } 2 \\
\text { receptor beta common } \\
\text { subunit }\end{array}$ & 5 & 26613780 & Milk production & 2016 \\
\hline NCF4 & Neutrophil cytosolic factor 4 & 5 & 26613780 & Milk production & 2016 \\
\hline CSN1S2 & Casein alpha-S2 & 6 & 15040897 & $\begin{array}{l}\text { Protein yield, protein percentage, fat yield, fat } \\
\text { percentage, milk yield) }\end{array}$ & 2004 \\
\hline CSN2 & Casein beta & 6 & 15040897 & $\begin{array}{l}\text { Protein yield, protein percentage, fat yield, fat } \\
\text { percentage, milk yield) }\end{array}$ & 2004 \\
\hline PPARGCIA & $\begin{array}{l}\text { Peroxisome proliferator- } \\
\text { activated receptor gamma, } \\
\text { coactivator } 1 \text { alpha }\end{array}$ & 6 & 15781588 & Milk fat & 2005 \\
\hline$S P P 1$ & Secreted phosphoprotein & 6 & 16230712 & $\begin{array}{l}\text { Milk production, milk protein percentage, } \\
\text { milk fat percentage }\end{array}$ & 2005 \\
\hline IL8 & Interleukin 8 & 6 & 17433017 & $\begin{array}{l}\text { Milk yield, fat yield, protein yield, somatic } \\
\text { cell score }\end{array}$ & 2007 \\
\hline$I G F B P 7$ & $\begin{array}{l}\text { Insulin-like growth factor- } \\
\text { binding protein } 7\end{array}$ & 6 & 21198698 & $\begin{array}{l}\text { Milk yield, 56-day non-return rate, interval } \\
\text { from first service to successful insemination } \\
\text { (heifer) }\end{array}$ & 2011 \\
\hline FAM13A1 & $\begin{array}{l}\text { Family with sequence } \\
\text { similarly } 13 \text {, member A }\end{array}$ & 6 & 21257065 & Milk yield, fat yield, fat percentage & 2011 \\
\hline$I G F B P-5$ & $\begin{array}{l}\text { Insulin-like growth factor- } \\
\text { binding protein-5 }\end{array}$ & 6 & 21338820 & $\begin{array}{l}\text { Calving ability, milk yield, protein yield, } \\
\text { mammary gland involution }\end{array}$ & 2011 \\
\hline PKD2 & Polycystic kidney disease 2 & 6 & 25148050 & Protein percentage & 2014 \\
\hline CSN1S1 & Casein alpha s1 & 6 & $\begin{array}{c}12939094 \\
15905454 \\
16840633\end{array}$ & $\begin{array}{l}\text { Milk yield, fat yield, protein yield, milk fat } \\
\text { percentage, milk protein percentage }\end{array}$ & $\begin{array}{l}2003, \\
2005 \\
2006\end{array}$ \\
\hline CSN3 & Casein kappa & 6 & 12939094,18666558 & $\begin{array}{l}\text { Milk yield, fat yield, protein yield, milk fat } \\
\text { percentage, milk protein percentage }\end{array}$ & $\begin{array}{l}2003, \\
2008\end{array}$ \\
\hline$A B C G 2$ & $\begin{array}{l}\text { ATP-binding cassette, } \\
\text { subfamily G }\end{array}$ & 6 & $\begin{array}{c}15998908, \\
17584938 \\
17106124\end{array}$ & Milk yield, milk fat and protein concentration & $\begin{array}{l}2005, \\
2007\end{array}$ \\
\hline PPARGC1A & $\begin{array}{l}\text { Proliferative peroxisome- } \\
\text { activated receptor, } \\
\text { coactivator } 1\end{array}$ & 6 & 22669841 & Milk performance & 2012 \\
\hline CASIA & Casein alpha s1 & 6 & 24456127 & Protein percentage & 2014 \\
\hline$L A R P 1$ & $\begin{array}{l}\text { La ribonucleoprotein domain } \\
\text { family, member } 1\end{array}$ & 7 & 24456127 & Somatic cell score & 2014 \\
\hline IRF1 & Interferon regulatory factor 1 & 7 & 24779965 & Lactation yields, involution pathways & 2014 \\
\hline GRIA1 & $\begin{array}{l}\text { Glutamate receptor, } \\
\text { ionotropic, AMPA1 }\end{array}$ & 7 & 25511820 & Milk fat composition, milk fat percentage & 2014 \\
\hline$C A S T$ & Calpastatin & 7 & 16734705,23759029 & $\begin{array}{l}\text { Daughter pregnancy rate, productive life, } \\
\text { protein yield, milk yield, fat yield, somatic } \\
\text { cell score, net merit, conception rate (heifer } \\
\text { and cow) }\end{array}$ & $\begin{array}{l}2006, \\
2013\end{array}$ \\
\hline$F B P 1$ & Fructose 1,6 bisphosphatase 1 & 8 & 22669841 & Milk performance & 2012 \\
\hline$F B P 2$ & Fructose 1,6 bisphosphatase 2 & 8 & 22669841 & Milk performance & 2012 \\
\hline TP53 & Tumour protein $\mathrm{p} 53$ & 9 & 17584498 & Lactation and involution, pregnancy, puberty & 2007 \\
\hline TEP1 & $\begin{array}{l}\text { Telomerase associated protein } \\
1\end{array}$ & 10 & 27506634 & Test day protein yield, test day fat yield & 2016 \\
\hline
\end{tabular}


Table 2 continued

\begin{tabular}{|c|c|c|c|c|c|}
\hline Gene & Gene name & Chromosome & PUBMED-ID & Trait & Year \\
\hline$P C K 2$ & $\begin{array}{l}\text { Phosphoenolpyruvate } \\
\text { carboxykinase } 2 \text {, } \\
\text { mitochondrial isoform }\end{array}$ & 10 & 22669841 & Milk performance & 2012 \\
\hline$G F I 1 B$ & $\begin{array}{l}\text { Growth factor independent } \\
\text { 1B transcription receptor }\end{array}$ & 11 & 21048968 & Fat percentage & 2010 \\
\hline$L G B$ & Lactoglobulin, beta & 11 & $\begin{array}{c}22192223 \\
19032698 \\
12836958\end{array}$ & $\begin{array}{l}\text { Milk protein composition, milk beta- } \\
\text { lactoglobulin protein concentration }\end{array}$ & $\begin{array}{l}2012, \\
2009 \\
2003\end{array}$ \\
\hline NLRP6 & $\begin{array}{l}\text { NLR family, pyrin domain- } \\
\text { containing } 6\end{array}$ & 11 & 24456127 & Mammary system & 2014 \\
\hline$P R K C E$ & Protein kinase $\mathrm{C}$, epsilon & 11 & 24456127 & Mammary system & 2014 \\
\hline NRXN1 & Neurexin 1 & 11 & 24456127 & Somatic cell score & 2014 \\
\hline$P A E P$ & $\begin{array}{l}\text { Progestogen-associated } \\
\text { endometrial protein }\end{array}$ & 11 & 26613780 & Milk production & 2016 \\
\hline$R N F 219$ & Ring finger protein 219 & 12 & 24456127 & Fat production & 2014 \\
\hline ACSS2 & $\begin{array}{l}\text { Acyl-CoA synthetase short- } \\
\text { chain family member } 2\end{array}$ & 13 & 21569316 & Fat yield, milk fatty acids & 2011 \\
\hline PLK1S1 & Kizuna centrosomal protein & 13 & 27506634 & Somatic cell score & 2016 \\
\hline$P C K 1$ & $\begin{array}{l}\text { Phosphoenolpyruvate } \\
\text { carboxykinase } 1 \text {, cytosolic } \\
\text { isoform }\end{array}$ & 13 & 22669841 & Milk performance & 2012 \\
\hline$C Y P 11 B 1$ & $\begin{array}{l}\text { Cytochrome P450, subfamily } \\
\text { XI B, polypeptide } 1\end{array}$ & 14 & 17179535 & $\begin{array}{l}\text { Milk production, somatic cell score, maternal } \\
\text { calving ease, } 90 \text {-day non-return rate } \\
\text { (maternal and paternal) }\end{array}$ & 2007 \\
\hline VPS28 & $\begin{array}{l}\text { Vacuolar protein sorting } 28 \\
\text { homolog }\end{array}$ & 14 & 21048968 & $\begin{array}{l}\text { Milk yield, protein percentage, fat yield, fat } \\
\text { percentage }\end{array}$ & 2010 \\
\hline$M A F 1$ & MAF1 homolog & 14 & 21048968 & Milk yield, fat percentage & 2010 \\
\hline$O P L A H$ & 5-oxoprolinase & 14 & 21048968 & Fat percentage & 2010 \\
\hline MAPK15 & $\begin{array}{l}\text { Mitogen-activated protein } \\
\text { kinase } 15\end{array}$ & 14 & 21048968 & Fat percentage & 2010 \\
\hline ZNF623 & Zinc finger protein 623 & 14 & 21048968 & Fat percentage, milk yield & 2010 \\
\hline$E E F 1 D$ & $\begin{array}{l}\text { Eukaryotic translation } \\
\text { elongation factor } 1 \text { delta }\end{array}$ & 14 & 21048968 & Fat percentage & 2010 \\
\hline ZC3H3 & $\begin{array}{l}\text { Zinc finger CCCH-type } \\
\text { containing } 3\end{array}$ & 14 & 21048968 & Fat percentage & 2010 \\
\hline$G M L$ & $\begin{array}{l}\text { Glycosylphosphatidylinositol } \\
\text { anchored molecule like }\end{array}$ & 14 & 21048968 & Fat percentage, milk yield & 2010 \\
\hline GPIHBP1 & $\begin{array}{l}\text { Glycosylphosphatidylinositol } \\
\text { anchored high density } \\
\text { lipoprotein-binding protein } \\
1\end{array}$ & 14 & 21048968 & Milk yield, protein yield, fat percentage & 2010 \\
\hline RHPN1 & $\begin{array}{l}\text { Rhophilin, Rho GTPase- } \\
\text { binding protein } 1\end{array}$ & 14 & 21048968 & Fat percentage & 2010 \\
\hline$P T K 2$ & Protein tyrosine kinase 2 & 14 & 21048968 & Fat percentage & 2010 \\
\hline KCNK9 & $\begin{array}{l}\text { Potassium channel, subfamily } \\
\text { K, member } 9\end{array}$ & 14 & 21048968 & Fat percentage & 2010 \\
\hline COL22A1 & Collagen, type XXII, alpha 1 & 14 & 21048968 & Milk yield, protein yield, fat percentage & 2010 \\
\hline KHDRBS3 & $\begin{array}{l}\text { KH domain-containing, RNA } \\
\text { binding, signal transduction } \\
\text { associated } 3\end{array}$ & 14 & 21048968 & Fat percentage & 2010 \\
\hline NIBP & IKK $\beta$-binding protein & 14 & 21831322 & Fat percentage & 2011 \\
\hline$C E B P D$ & $\begin{array}{l}\text { CCAAT/enhancer-binding } \\
\text { protein }\end{array}$ & 14 & 24779965 & Involution pathways & 2014 \\
\hline
\end{tabular}


Table 2 continued

\begin{tabular}{|c|c|c|c|c|c|}
\hline Gene & Gene name & Chromosome & PUBMED-ID & Trait & Year \\
\hline$M Y C$ & $\begin{array}{l}\text { v-myc avian } \\
\text { myelocytomatosis viral } \\
\text { oncogene homolog }\end{array}$ & 14 & 24779965 & Involution pathways & 2014 \\
\hline CYHRI & Cysteine/histidine-rich 1 & 14 & 25511820,27287773 & $\begin{array}{l}\text { Milk fat composition, milk fat percentage, } \\
\text { milk production }\end{array}$ & $\begin{array}{l}2014, \\
2016\end{array}$ \\
\hline ARHGAP39 & $\begin{array}{l}\text { Rho GTPase-activating } \\
\text { protein } 39\end{array}$ & 14 & 25511820,27287773 & $\begin{array}{l}\text { Milk fat composition, milk fat percentage, fat } \\
\text { production }\end{array}$ & $\begin{array}{l}2014, \\
2016\end{array}$ \\
\hline CPSF1 & $\begin{array}{l}\text { Cleavage and polyadenylation } \\
\text { specific factor } 1\end{array}$ & 14 & 25511820 & Milk fat composition, milk fat percentage & 2014 \\
\hline GRINA & $\begin{array}{l}\text { Glutamate receptor, } \\
\text { ionotropic, } N \text {-methyl D- } \\
\text { aspartate-associated protein } \\
1\end{array}$ & 14 & 25511820 & Milk fat composition, milk fat percentage & 2014 \\
\hline FAM $83 H$ & $\begin{array}{l}\text { Family with sequence } \\
\text { similarity } 83 \text {, member } \mathrm{H}\end{array}$ & 14 & 25511820 & Milk fat composition, milk fat percentage & 2014 \\
\hline DGAT1 & $\begin{array}{l}\text { Diacylglycerol } O- \\
\text { acyltransferase } 1\end{array}$ & 14 & $\begin{array}{c}11827942, \\
16621755 \\
17179535 \\
18650297 \\
18666558 \\
18669245\end{array}$ & $\begin{array}{l}\text { Milk yield and composition, milk protein } \\
\text { yield, milk fat yield, milk fat and protein } \\
\text { percentage, somatic cell score, maternal } \\
\text { non-return rate, productive life, } \\
\text { conformation traits }\end{array}$ & $\begin{array}{l}2002, \\
2006, \\
2007, \\
2008\end{array}$ \\
\hline$C Y P 11 B 1$ & $\begin{array}{l}\text { Cytochrome } \mathrm{P} 450 \text {, subfamily } \\
\text { XI B, polypeptide } 1\end{array}$ & 14 & 21048968,17179535 & $\begin{array}{l}\text { Milk yield, fat yield, protein yield, milk fat } \\
\text { percentage, milk protein percentage, } \\
\text { somatic cell score, maternal calving ease, } \\
\text { 90-day non-return rate (paternal and } \\
\text { maternal) }\end{array}$ & $\begin{array}{l}2010, \\
2007\end{array}$ \\
\hline$A D C K 5$ & $\begin{array}{l}\text { AarF domain-containing } \\
\text { kinase } 5\end{array}$ & 14 & 27506634 & Test day fat yield (milk fat $\%$ ) & 2016 \\
\hline TONSL & $\begin{array}{l}\text { Tonsoku-like, DNA repair } \\
\text { protein }\end{array}$ & 14 & 27506634,27287773 & $\begin{array}{l}\text { Test day fat yield (milk fat } \% \text { ), milk } \\
\text { production }\end{array}$ & 2016 \\
\hline PPP1R16A & $\begin{array}{l}\text { Protein phosphatase } 1 \\
\text { regulatory subunit } 16 \mathrm{~A}\end{array}$ & 14 & 27506634,27287773 & $\begin{array}{l}\text { Test day fat yield (milk fat } \% \text { ), milk } \\
\text { production }\end{array}$ & 2016 \\
\hline TRAPPC9 & $\begin{array}{l}\text { Trafficking protein particle } \\
\text { complex } 9\end{array}$ & 14 & 27506634 & Test day fat yield (milk fat $\%$ ) & 2016 \\
\hline$L R R C 14$ & $\begin{array}{l}\text { Leucine-rich repeat- } \\
\text { containing } 14\end{array}$ & 14 & 27506634 & 305-day fat yield, lactose percentage & 2016 \\
\hline FOXH1 & Forkhead box H1 & 14 & 27287773 & Milk production & 2016 \\
\hline PPP1R16A & $\begin{array}{l}\text { Protein phosphatase } 1 \\
\text { regulatory subunit } 16 \mathrm{~A}\end{array}$ & 14 & 27287773 & Fat production, and fat percentage & 2016 \\
\hline SMPD5 & $\begin{array}{l}\text { Sphingomyelin } \\
\text { phosphodiesterase } 5\end{array}$ & 14 & 27287773 & Fat production, and fat percentage & 2016 \\
\hline $\mathrm{MROH} 1$ & $\begin{array}{l}\text { Maestro heat like repeat } \\
\text { family member } 1\end{array}$ & 14 & 27287773 & Fat production, and fat percentage & 2016 \\
\hline$E I F 2 C 2$ & $\begin{array}{l}\text { Argonaute } 2 \text {, RISC catalytic } \\
\text { component }\end{array}$ & 14 & 25510969 & Milk yield, fat yield, protein yield & 2014 \\
\hline TRAPPC9 & $\begin{array}{l}\text { Trafficking protein particle } \\
\text { complex } 9\end{array}$ & 14 & 25510969 & Milk yield, fat yield, protein yield & 2014 \\
\hline HEATR7A & $\begin{array}{l}\text { Maestro heat like repeat } \\
\text { family member } 1\end{array}$ & 14 & 25510969 & Fat percentage & 2014 \\
\hline TRAPPC9 & $\begin{array}{l}\text { Trafficking protein particle } \\
\text { complex } 9\end{array}$ & 14 & 25510969 & Milk yield, fat yield, protein yield & 2014 \\
\hline$N E U 3$ & Sialidase 3 & 15 & 23759029 & $\begin{array}{l}\text { Conception rate (heifer and cow), productive } \\
\text { life }\end{array}$ & 2013 \\
\hline$C D 44$ & $\begin{array}{l}\text { CD } 44 \text { molecule (Indian blood } \\
\text { group) }\end{array}$ & 15 & 27287773 & Milk production & 2016 \\
\hline
\end{tabular}


Table 2 continued

\begin{tabular}{|c|c|c|c|c|c|}
\hline Gene & Gene name & Chromosome & PUBMED-ID & Trait & Year \\
\hline$L A X 1$ & $\begin{array}{l}\text { Lymphocyte transmembrane } \\
\text { adaptor } 1\end{array}$ & 16 & 27006194 & Milk yield & 2016 \\
\hline$A D C K 3$ & $\begin{array}{l}\text { AarF domain-containing } \\
\text { kinase } 3\end{array}$ & 16 & 24456127 & Somatic cell score & 2014 \\
\hline$F G F 2$ & Fibroblast growth factor 2 & 17 & 18487671 & Milk fat, productive life & 2008 \\
\hline RILPL2 & $\begin{array}{l}\text { Rab-interacting lysosomal } \\
\text { protein-like } 2\end{array}$ & 17 & 27506634 & Somatic cell score & 2016 \\
\hline NOD2 & $\begin{array}{l}\text { Nucleotide-binding } \\
\text { oligomerization domain- } \\
\text { containing 2, CARD15 }\end{array}$ & 18 & 18005441 & Milk yield, somatic cell score & 2007 \\
\hline PGLYRP1 & $\begin{array}{l}\text { Peptidoglycan recognition } \\
\text { protein } 1\end{array}$ & 18 & 21831322 & $\begin{array}{l}\text { Fat yield, protein yield, service-sire, daughter } \\
\text { calving-ease, net merit, milk yield, } \\
\text { productive life, fat percentage, protein } \\
\text { percentage }\end{array}$ & 2011 \\
\hline IGFLI & $\begin{array}{l}\text { Insulin growth factor-like } \\
\text { family member } 1\end{array}$ & 18 & 21831322 & $\begin{array}{l}\text { Fat yield, protein yield, service-sire, daughter } \\
\text { calving-ease, net merit, milk yield, } \\
\text { productive life, fat percentage, protein } \\
\text { percentage }\end{array}$ & 2011 \\
\hline$T G F B 1$ & $\begin{array}{l}\text { Transforming growth factor, } \\
\text { beta } 1\end{array}$ & 18 & 24779965 & $\begin{array}{l}\text { Mammary development pathways, milk } \\
\text { production }\end{array}$ & 2014 \\
\hline$G H$ & Growth hormone & 19 & 16388132 & Milk yield, lactation & 2005 \\
\hline FASN & Fatty acid synthase & 19 & 17242864 & Milk fat, milk fatty acids & 2007 \\
\hline$C C L 2$ & Chemokine & 19 & 17433017 & $\begin{array}{l}\text { Milk yield, fat yield, protein yield, somatic } \\
\text { cell score }\end{array}$ & 2007 \\
\hline$A C L Y$ & ATP citrate lyase & 19 & 19389950 & Fatty acid biosynthesis & 2009 \\
\hline BAIAP2 & BAI1-associated protein 2 & 19 & 21198698 & $\begin{array}{l}\text { Fat percentage, protein percentage, 56-day } \\
\text { non-return rate (heifer) }\end{array}$ & 2011 \\
\hline$S R E B F 1$ & $\begin{array}{l}\text { Sterol regulatory element- } \\
\text { binding transcription factor } \\
1\end{array}$ & 19 & 21569316 & Fat yield, milk fatty acids & 2011 \\
\hline STAT5B & $\begin{array}{l}\text { Signal transducer and } \\
\text { activator of transcription } 5 \mathrm{~B}\end{array}$ & 19 & 24779965 & $\begin{array}{l}\text { Mammary development pathways, involution } \\
\text { pathways, prolactin signalling pathways }\end{array}$ & 2014 \\
\hline STAT5A & $\begin{array}{l}\text { Signal transducer and } \\
\text { activator of transcription } 5 \mathrm{~A}\end{array}$ & 19 & 15523155,18218766 & $\begin{array}{l}\text { Milk yield, milk fat and protein content, } \\
\text { fertilization rate, embryonic survival }\end{array}$ & $\begin{array}{l}2004, \\
2008\end{array}$ \\
\hline$G H D C$ & GH3 domain containing & 19 & 26613780 & Milk production & 2016 \\
\hline GHR & Growth hormone receptor & 20 & 12586713 & Milk yield and composition & 2003 \\
\hline$F Y B$ & FYN-binding protein & 20 & 21048968 & Protein percentage & 2010 \\
\hline RICTOR & $\begin{array}{l}\text { RPTOR independent } \\
\text { companion of MTOR, } \\
\text { complex } 2\end{array}$ & 20 & 21048968 & Protein percentage & 2010 \\
\hline CCNB1 & Cyclin B1 & 20 & 21198698 & $\begin{array}{l}\text { 56-day non-return rate (cow and heifer), milk } \\
\text { yield }\end{array}$ & 2011 \\
\hline$G D N F$ & $\begin{array}{l}\text { Glial cell-derived } \\
\text { neurotrophic factor }\end{array}$ & 20 & 22281351 & $\begin{array}{l}\text { Milk yield, fat yield, protein yield, protein } \\
\text { and fat composition }\end{array}$ & 2012 \\
\hline$P R L R$ & Prolactin receptor & 20 & 24779965 & $\begin{array}{l}\text { Mammary development pathways, involution } \\
\text { pathways, prolactin signalling pathways }\end{array}$ & 2014 \\
\hline LIFR & $\begin{array}{l}\text { Leukaemia inhibitory factor } \\
\text { receptor alpha }\end{array}$ & 20 & 24779965 & $\begin{array}{l}\text { Mammary development pathways, involution } \\
\text { pathways, prolactin signalling pathways }\end{array}$ & 2014 \\
\hline OSMR & Oncostatin $\mathrm{M}$ receptor & 20 & 24779965 & Involution pathways & 2014 \\
\hline ISL1 & ISL LIM homeobox 1 & 20 & 24456127 & Mammary system & 2014 \\
\hline$L T F$ & Lactotransferrin & 22 & 16621755,18666558 & $\begin{array}{l}\text { Fat yield, protein yield, fat percentage, } \\
\text { protein percentage }\end{array}$ & $\begin{array}{l}2006 \\
2008\end{array}$ \\
\hline$B O L A-D R B 3$ & $\begin{array}{l}\text { Major histocompatibility } \\
\text { complex, class II, DRB3 }\end{array}$ & 23 & 10376308 & 305-day milk, fat yield, protein yield & 1999 \\
\hline
\end{tabular}


Table 2 continued

\begin{tabular}{|c|c|c|c|c|c|}
\hline Gene & Gene name & Chromosome & PUBMED-ID & Trait & Year \\
\hline$P R L$ & Prolactin & 23 & 15523155 & Milk protein, milk yield, milk composition & 2004 \\
\hline JARID2 & $\begin{array}{l}\text { Jumonji, AT-rich interactive } \\
\text { domain } 2\end{array}$ & 23 & 25148050 & Protein yield & 2014 \\
\hline HSPA1A & $\begin{array}{l}\text { Heat shock } 70 \mathrm{kDa} \text { protein } \\
1 \mathrm{~A}\end{array}$ & 23 & 23759029,20059932 & $\begin{array}{l}\text { Productive life, fat percent, net merit, protein } \\
\text { percent, calving rate }\end{array}$ & $\begin{array}{l}2013, \\
2010\end{array}$ \\
\hline TRIM26 & Tripartite motif-containing 26 & 23 & 27006194 & Fat yield & 2016 \\
\hline$P M M 2$ & Phosphomannomutase 2 & 25 & 23759029 & $\begin{array}{l}\text { Daughter pregnancy rate, conception rate } \\
\text { (cow), productive life, protein percent }\end{array}$ & 2013 \\
\hline CLEC16A & $\begin{array}{l}\text { C-type lectin domain family } \\
16 \text { member A }\end{array}$ & 25 & 27006194 & Fat yield & 2016 \\
\hline $\begin{array}{r}\text { PAM16/ } \\
\text { GLIS2 }\end{array}$ & GLIS family zinc finger 2 & 25 & 27006194 & Milk yield, protein yield & 2016 \\
\hline$B T R C$ & $\begin{array}{l}\text { Beta-transducin repeat } \\
\text { containing }\end{array}$ & 26 & 24456127 & Fat yield & 2014 \\
\hline PLCE1 & Phospholipase C, epsilon 1 & 26 & 24456127 & Protein yield & 2014 \\
\hline$S U F U$ & Suppressor of fused homolog & 26 & 24456127 & Mammary system & 2014 \\
\hline$D K K 1$ & $\begin{array}{l}\text { Dickkopf WNT signalling } \\
\text { pathway inhibitor } 1\end{array}$ & 26 & 24779965 & $\begin{array}{l}\text { Mammary development pathways, milk } \\
\text { production }\end{array}$ & 2014 \\
\hline$S C D$ & Stearoyl-CoA desaturase & 26 & 25511820 & Milk fat composition, milk fat percentage & 2014 \\
\hline$S C D 1$ & Stearoyl-CoA desaturase 1 & 26 & 21569316,15058385 & Milk fatty acid content & $\begin{array}{l}2011 \\
2005\end{array}$ \\
\hline NEURL1 & $\begin{array}{l}\text { Neuralized E3 ubiquitin } \\
\text { protein ligase } 1\end{array}$ & 26 & 27006194 & Fat yield & 2016 \\
\hline GINS4 & GINS complex subunit 4 & 27 & 24456127 & Fat percentage & 2014 \\
\hline AGPAT6 & $\begin{array}{l}\text { 1-acylglycerol-3-phosphate } \\
O \text {-acyltransferase } 6\end{array}$ & 27 & 21569316,24465687 & Milk fatty acid content, milk fat percentage & $\begin{array}{l}2011 \\
2014\end{array}$ \\
\hline FADS1 & Fatty acid desaturase 1 & 29 & 27506634,24533445 & Milk omega-3 FA synthesis & $\begin{array}{l}2016, \\
2014\end{array}$ \\
\hline$F A D S 2$ & Fatty acid desaturase 2 & 29 & 27506634,24533445 & Milk omega-6 synthesis & $\begin{array}{l}2016, \\
2014\end{array}$ \\
\hline
\end{tabular}

to the MGSTl gene on chromosome 5 have been shown to be associated with increased fat yield, protein percentage and lactose percentage, and a decrease in protein yield, lactose yield and protein volume [91]. Through the collection and analysis of gene expression data the authors demonstrate that a strong MGST1 eQTL (expression QTL) likely underlies these associations, however the specific role of MGST1 in regulating milk composition is not known [91]. The identification of genes that influence multiple production traits is not surprising given the shared underlying molecular mechanisms [140]. For example, it has been shown that the main functional pathways that are regulated by the $K 232 A$ polymorphism in DGATI gene (associated with reduced milk production and increased milk fat yield) were related to cell energy metabolism (lipid biosynthesis, oxidative phosphorylation, electron transport chain), protein degradation and cell signalling [97]. This might reflect the underlying biological pleiotropic effect, where a single casual variant is related to the variations in multiple traits as explained by Solovieff et al. [140].

Regions and candidate genes associated with multiple fertility traits have been described. For example, chromosome 21 was shown to harbour a region overlapping among two fertility traits, calving to first service interval and days open, and a candidate gene in that region has been proposed, FAM181A [111]. In another GWAS study in Nordic Red cattle, a shared significant SNP (rs43271631) on chromosome 1 was associated with multiple fertility traits such as fertility index, 56-day non-return rate, number of insemination per conception and days from first to last insemination [57]. This SNP is located within an intron of the TRPC1 gene, which was shown to regulate osteoblast formation in mice [114]. Cole et al. [30] reported a common SNP (ss86324977) on chromosome 18 in an intronic region of the sialic acid-binding Ig-like lectin-5 (SIGLEC5) gene, associated with sire and daughter calving ease, that was also reported to affect direct calving traits in multiple 
Table 3 List of major candidate genes identified through association studies for fertility traits in dairy cattle

\begin{tabular}{|c|c|c|c|c|c|}
\hline Gene & Gene name & Chromosome & PUBMED-ID & Trait & Year \\
\hline$P C C B$ & $\begin{array}{l}\text { Propionyl CoA carboxylase, } \\
\text { beta polypeptide }\end{array}$ & 1 & 23759029 & Daughter pregnancy rate & 2013 \\
\hline TRPC1 & $\begin{array}{l}\text { Transient receptor potential } \\
\text { cation channel subfamily C } \\
\text { member } 1\end{array}$ & 1 & 26369327 & $\begin{array}{l}\text { Female fertility index, 56-day non-return rate, } \\
\text { number of inseminations per conception }\end{array}$ & 2015 \\
\hline$I G F B P 2$ & $\begin{array}{l}\text { Insulin-like growth factor- } \\
\text { binding protein } 2,36 \mathrm{kDa}\end{array}$ & 2 & 21198698 & Lactation, establishment of pregnancy & 2011 \\
\hline$T S H B$ & $\begin{array}{l}\text { Thyroid stimulating hormone, } \\
\text { beta }\end{array}$ & 3 & 23759029 & Daughter pregnancy rate & 2013 \\
\hline WDR77 & $\begin{array}{l}\text { Bos taurus WD repeat } \\
\text { domain } 77\end{array}$ & 3 & 25216717 & Heifer non-return rate & 2015 \\
\hline$V A V 3$ & $\begin{array}{l}\text { Vav guanine nucleotide } \\
\text { exchange factor } 3\end{array}$ & 3 & 25216717 & Days from first to last insemination & 2015 \\
\hline CD36 & Platelet glycoprotein 4 & 4 & 25216717 & $\begin{array}{l}\text { Number of inseminations, 56-day non-return } \\
\text { rate, days from first to last insemination, the } \\
\text { interval from calving to first insemination }\end{array}$ & 2014 \\
\hline$L E P$ & Leptin & 4 & $\begin{array}{c}15905454 \\
18565947 \\
18650297 \\
15927775\end{array}$ & $\begin{array}{l}\text { Milk protein, milk fat, lactation performance, } \\
\text { health, daily milk reproduction, postpartum } \\
\text { luteal activity }\end{array}$ & $\begin{array}{l}2005, \\
2008\end{array}$ \\
\hline$A D C Y 1$ & Adenylate cyclase 1 & 4 & 24428918,18565942 & $\begin{array}{l}\text { Number of inseminations, 56-day non-return } \\
\text { rate, days from first to last insemination, the } \\
\text { interval from calving to first insemination, } \\
\text { mammary system, conformation traits, } \\
\text { daughter fertility, calving ease }\end{array}$ & $\begin{array}{l}2014, \\
2008\end{array}$ \\
\hline SEMA3C & $\begin{array}{l}\text { Sema domain, } \\
\text { immunoglobulin domain } \\
\text { (Ig), short basic domain, } \\
\text { secreted, (semaphorin) } 3 \mathrm{C}\end{array}$ & 4 & 25216717 & $\begin{array}{l}\text { Number of insemination per conception; days } \\
\text { from first to last insemination; 56-day non- } \\
\text { return rate; the length in days of the interval } \\
\text { from calving to first insemination }\end{array}$ & 2014 \\
\hline GNAT3 & $\begin{array}{l}\text { G protein subunit alpha } \\
\text { transducin } 3\end{array}$ & 4 & 25216717 & $\begin{array}{l}\text { Number of insemination per conception; days } \\
\text { from first to last insemination; 56-day non- } \\
\text { return rate; the length in days of the interval } \\
\text { from calving to first insemination }\end{array}$ & 2014 \\
\hline CSNK1E & Casein kinase 1, epsilon & 5 & 23759029 & $\begin{array}{l}\text { Daughter pregnancy rate, heifer conception } \\
\text { rate, productive life }\end{array}$ & 2013 \\
\hline$I G F 1$ & Insulin-like growth factor 1 & 5 & 24265800 & Days to first service & 2013 \\
\hline$A M H R 2$ & $\begin{array}{l}\text { Anti-mullerian hormone } \\
\text { receptor type II }\end{array}$ & 5 & 24265800 & Calving interval & 2013 \\
\hline CPT1B & $\begin{array}{l}\text { Carnitine } \\
\text { palmitoyltransferase 1B }\end{array}$ & 5 & 24265800 & 56-day non-return rate & 2013 \\
\hline$A T P 2 B 1$ & $\begin{array}{l}\text { ATPase, } \mathrm{Ca}++ \text { transporting } \\
\text { plasma membrane } 1\end{array}$ & 5 & $\begin{array}{c}24265800 \\
19448026 \\
12926772\end{array}$ & $\begin{array}{l}\text { Calving interval, 56-day non-return rate, days } \\
\text { to first service, } 305 \text {-day first parity lactation, } \\
\text { fat yield, protein yield }\end{array}$ & $\begin{array}{l}2013, \\
2009 \\
2003\end{array}$ \\
\hline SOX5 & $\begin{array}{l}\text { SRY (sex-determining region } \\
\text { Y)-box } 5\end{array}$ & 5 & 24456127 & Fertility & 2014 \\
\hline$I G F B P 7$ & $\begin{array}{l}\text { Insulin-like growth factor- } \\
\text { binding protein } 7\end{array}$ & 6 & 21198698 & $\begin{array}{l}\text { Milk yield, 56-day non-return rate, interval } \\
\text { from first service to successful insemination } \\
\text { (heifer) }\end{array}$ & 2011 \\
\hline$I G F B P-5$ & $\begin{array}{l}\text { Insulin-like growth factor- } \\
\text { binding protein-5 }\end{array}$ & 6 & 21338820 & $\begin{array}{l}\text { Calving ability, milk yield, protein yield, } \\
\text { mammary gland involution }\end{array}$ & 2011 \\
\hline CLOCK & Clock circulation regulator & 6 & 23759029 & Daughter pregnancy rate & 2013 \\
\hline GPR125 & $\begin{array}{l}\text { Adhesion } \mathrm{G} \text { protein-coupled } \\
\text { receptor A3 }\end{array}$ & 6 & 26369327 & Female fertility index & 2015 \\
\hline$N P F F R 2$ & Neuropeptide FF receptor 2 & 6 & 24456127 & Fertility & 2014 \\
\hline
\end{tabular}


Table 3 continued

\begin{tabular}{|c|c|c|c|c|c|}
\hline Gene & Gene name & Chromosome & PUBMED-ID & Trait & Year \\
\hline$E P G N$ & Epithelial mitogen & 6 & 26613780 & Calving interval & 2016 \\
\hline CSF2 & Colony-stimulating factor 2 & 7 & 23759029 & Daughter pregnancy rate & 2013 \\
\hline CAST & Calpastatin & 7 & 16734705,23759029 & $\begin{array}{l}\text { Daughter pregnancy rate, productive life, } \\
\text { protein yield, milk yield, fat yield, somatic } \\
\text { cell score, net merit, conception rate (heifer } \\
\text { and cow) }\end{array}$ & $\begin{array}{l}2006, \\
2013\end{array}$ \\
\hline TP53 & Tumour protein $\mathrm{p} 53$ & 9 & 17584498 & Lactation and involution, pregnancy, puberty & 2007 \\
\hline ACAT2 & $\begin{array}{l}\text { Acetyl-CoA acetyltransferase } \\
2\end{array}$ & 9 & 23759029 & $\begin{array}{l}\text { Daughter pregnancy rate, conception rate } \\
\text { (cow and heifer), productive life }\end{array}$ & 2013 \\
\hline WDR27 & WD repeat domain 27 & 9 & 24456127 & Survival & 2014 \\
\hline$S L C 1 A 4$ & Solute carrier family 1 & 11 & 24428918 & $\begin{array}{l}\text { 56-day non-return rate (cow), days interval } \\
\text { from calving to first service }\end{array}$ & 2014 \\
\hline$P P M 1 B$ & $\begin{array}{l}\text { Protein phosphatase } \mathrm{Mg} 2+l \\
\mathrm{Mn} 2+\text { dependent, } 1 \mathrm{~B}\end{array}$ & 11 & 24428918 & $\begin{array}{l}\text { 56-day non-return rate (cow), days interval } \\
\text { from calving to first service }\end{array}$ & 2014 \\
\hline FSHR & $\begin{array}{l}\text { Follicle stimulating hormone } \\
\text { receptor }\end{array}$ & 11 & 23759029,20207511 & $\begin{array}{l}\text { Conception rate (heifer), productive life, } \\
\text { superovulation response }\end{array}$ & $\begin{array}{l}2013, \\
2010\end{array}$ \\
\hline NLRP6 & $\begin{array}{l}\text { NLR family, pyrin domain- } \\
\text { containing } 6\end{array}$ & 11 & 24456127 & Survival & 2014 \\
\hline HNF4A & $\begin{array}{l}\text { Hepatocyte nuclear factor } 4 \text {, } \\
\text { alpha }\end{array}$ & 13 & 23759029 & Daughter pregnancy rate & 2013 \\
\hline$C A C N B 2$ & $\begin{array}{l}\text { Calcium channel, voltage- } \\
\text { dependent, beta } 2 \text { subunit }\end{array}$ & 13 & 25216717 & $\begin{array}{l}\text { Number of inseminations, 56-day non-return } \\
\text { rate, days from first to last insemination, the } \\
\text { interval from calving to first insemination }\end{array}$ & 2014 \\
\hline ZEB1 & $\begin{array}{l}\text { Zinc finger E-box-binding } \\
\text { homeobox } 1\end{array}$ & 13 & 25216717 & $\begin{array}{l}\text { Number of inseminations, 56-day non-return } \\
\text { rate, days from first to last insemination, the } \\
\text { interval from calving to first insemination }\end{array}$ & 2014 \\
\hline ARHGAP12 & $\begin{array}{l}\text { Rho GTPase-activating } \\
\text { protein } 12\end{array}$ & 13 & 25216717 & $\begin{array}{l}\text { Number of inseminations, 56-day non-return } \\
\text { rate, days from first to last insemination, the } \\
\text { interval from calving to first insemination }\end{array}$ & 2014 \\
\hline ANKRD60 & Ankyrin repeat domain 60 & 13 & 26369327 & Female fertility index & 2015 \\
\hline ANKRD60 & Ankyrin repeat domain 60 & 13 & 25216717 & $\begin{array}{l}\text { Female fertility index; days from first to last } \\
\text { insemination }\end{array}$ & 2015 \\
\hline$C Y P 11 B 1$ & $\begin{array}{l}\text { Cytochrome } \mathrm{P} 450 \text {, subfamily } \\
\text { XI B, polypeptide } 1\end{array}$ & 14 & 17179535 & $\begin{array}{l}\text { Milk production, somatic cell score, maternal } \\
\text { calving ease, 90-day non-return rate } \\
\text { (maternal and paternal) }\end{array}$ & 2007 \\
\hline PLAG1 & PLAG1 zinc finger & 14 & 22100599 & Calving ease & 2012 \\
\hline$M O S$ & $\begin{array}{l}\text { V-mos Moloney murine } \\
\text { sarcoma viral oncogene } \\
\text { homolog }\end{array}$ & 14 & 22100599 & Reproduction rate & 2012 \\
\hline TOX & $\begin{array}{l}\text { Thymocyte selection- } \\
\text { associated high mobility } \\
\text { group box }\end{array}$ & 14 & 22100599 & Age at puberty & 2012 \\
\hline CSPP1 & $\begin{array}{l}\text { Centrosome and spindle pole } \\
\text { associated protein } 1\end{array}$ & 14 & 23759029 & Daughter pregnancy rate & 2013 \\
\hline CPSF1 & $\begin{array}{l}\text { Cleavage and } \\
\text { polyadenylation specific } \\
\text { factor } 1,160 \mathrm{kDa}\end{array}$ & 14 & 23759029 & Daughter pregnancy rate & 2013 \\
\hline DGAT1 & $\begin{array}{l}\text { Diacylglycerol } O \text { - } \\
\text { acyltransferase } 1\end{array}$ & 14 & $\begin{array}{c}11827942, \\
16621755 \\
17179535 \\
18650297 \\
18666558 \\
18669245\end{array}$ & $\begin{array}{l}\text { Milk yield and composition, milk protein } \\
\text { yield, milk fat yield, milk fat and protein } \\
\text { percentage, somatic cell score, maternal } \\
\text { non-return rate, productive life, } \\
\text { conformation traits }\end{array}$ & $\begin{array}{l}2002, \\
2006, \\
2007, \\
2008\end{array}$ \\
\hline
\end{tabular}


Table 3 continued

\begin{tabular}{|c|c|c|c|c|c|}
\hline Gene & Gene name & Chromosome & PUBMED-ID & Trait & Year \\
\hline$C Y P 11 B 1$ & $\begin{array}{l}\text { Cytochrome } \mathrm{P} 450 \text {, subfamily } \\
\text { XI B, polypeptide } 1\end{array}$ & 14 & 21048968,17179535 & $\begin{array}{l}\text { Milk yield, fat yield, protein yield, milk fat } \\
\text { percentage, milk protein percentage, somatic } \\
\text { cell score, maternal calving ease, } 90 \text {-day } \\
\text { non-return rate (paternal and maternal) }\end{array}$ & $\begin{array}{r}2010, \\
2007\end{array}$ \\
\hline CD82 & CD82 molecule & 15 & 21831322 & Daughter stillbirth & 2011 \\
\hline$P G R$ & Progesterone receptor-like & 15 & 23759029,23076525 & $\begin{array}{l}\text { In vitro fertilization or development, daughter } \\
\text { pregnancy rate }\end{array}$ & 2013 \\
\hline$H S D 17 B 12$ & $\begin{array}{l}\text { Hydroxysteroid } 17 \text {-beta } \\
\text { dehydrogenase } 12\end{array}$ & 15 & 23759029 & Daughter pregnancy rate & 2013 \\
\hline NEU3 & Neuraminidase 3 & 15 & 23759029 & $\begin{array}{l}\text { Conception rate (heifer and cow), productive } \\
\text { life }\end{array}$ & 2013 \\
\hline GRAMD1B & $\begin{array}{l}\text { GRAM domain-containing } \\
\text { 1B }\end{array}$ & 15 & 26369327 & Female fertility index & 2015 \\
\hline PAPPA2 & Pappalysin 2 & 16 & 22100599 & Pregnancy rate, daughter calving ease & 2012 \\
\hline MTOR & $\begin{array}{l}\text { Mechanistic target of } \\
\text { rapamycin }\end{array}$ & 16 & 22100599 & $\begin{array}{l}\text { Reproduction rate (regulation of } \mathrm{GnRH} \\
\text { release before the initiation of ovarian } \\
\text { cycling) }\end{array}$ & 2012 \\
\hline DYRK3 & Dual-specificity tyrosine & 16 & 23759029 & Daughter pregnancy rate & 2013 \\
\hline$T G F B 2$ & $\begin{array}{l}\text { Transforming growth factor, } \\
\text { beta } 2\end{array}$ & 16 & 24265800 & Number of days open & 2013 \\
\hline IGLLI & $\begin{array}{l}\text { Immunoglobulin lambda-like } \\
\text { polypeptide } 1\end{array}$ & 17 & 24265800 & Fertility index & 2013 \\
\hline PGLYRP1 & $\begin{array}{l}\text { Peptidoglycan recognition } \\
\text { protein } 1\end{array}$ & 18 & 21831322 & $\begin{array}{l}\text { Fat yield, protein yield, service-sire, daughter } \\
\text { calving-ease, net merit, milk yield, } \\
\text { productive life, fat percentage, protein } \\
\text { percentage }\end{array}$ & 2011 \\
\hline$I G F L 1$ & $\begin{array}{l}\text { Insulin growth factor-like } \\
\text { family member } 1\end{array}$ & 18 & 21831322 & $\begin{array}{l}\text { Fat yield, protein yield, service-sire, daughter } \\
\text { calving-ease, net merit, milk yield, } \\
\text { productive life, fat percentage, protein } \\
\text { percentage }\end{array}$ & 2011 \\
\hline ZNF541 & Zinc finger protein 541 & 18 & 22742504 & Sire conception rate & 2012 \\
\hline COQ9 & Coenzyme Q9 & 18 & 23759029 & Daughter pregnancy rate & 2013 \\
\hline$B A I A P 2$ & BAI1-associated protein 2 & 19 & 21198698 & $\begin{array}{l}\text { Fat percentage, protein percentage, 56-day } \\
\text { non-return rate (heifer) }\end{array}$ & 2011 \\
\hline PER1 & Period circadian clock 1 & 19 & 23759029 & Daughter pregnancy rate & 2013 \\
\hline$A P O H$ & Apolipoprotein $\mathrm{H}$ & 19 & 24265800 & $\begin{array}{l}\text { Production traits, days to first service, 56-day } \\
\text { non-return rate }\end{array}$ & 2013 \\
\hline STAT5A & $\begin{array}{l}\text { Signal transducer and } \\
\text { activator of transcription } 5 \mathrm{~A}\end{array}$ & 19 & 15523155,18218766 & $\begin{array}{l}\text { Milk yield, milk fat and protein content, } \\
\text { fertilization rate, embryonic survival }\end{array}$ & $\begin{array}{r}2004, \\
2008\end{array}$ \\
\hline$C C N B 1$ & Cyclin B1 & 20 & 21198698 & $\begin{array}{l}\text { 56-day non-return rate (cow and heifer), milk } \\
\text { yield }\end{array}$ & 2011 \\
\hline OCLN & Occludin & 20 & 23759029 & Daughter pregnancy rate & 2013 \\
\hline MIER3 & $\begin{array}{l}\text { Mesoderm induction } \\
\text { early response } 1 \text {, family } \\
\text { member } 3 \text {-like }\end{array}$ & 20 & 24456127 & Survival & 2014 \\
\hline CACNA1D & $\begin{array}{l}\text { Calcium channel, voltage- } \\
\text { dependent, L-type, alpha } \\
\text { 1D subunit }\end{array}$ & 22 & 23759029 & Daughter pregnancy rate & 2013 \\
\hline MOCS1 & $\begin{array}{l}\text { Molybdenum cofactor } \\
\text { synthesis } 1\end{array}$ & 23 & 21831322 & Daughter stillbirth & 2011 \\
\hline HSPA1A & $\begin{array}{l}\text { Heat shock } 70 \mathrm{kDa} \text { protein } \\
1 \mathrm{~A}\end{array}$ & 23 & 23759029,20059932 & $\begin{array}{l}\text { Productive life, fat percent, net merit, protein } \\
\text { percent, calving rate }\end{array}$ & $\begin{array}{r}2013, \\
2010\end{array}$ \\
\hline ZNF521 & Zinc finger protein 521 & 24 & 26369327 & Female fertility index & 2015 \\
\hline
\end{tabular}


Table 3 continued

\begin{tabular}{lllll}
\hline Gene & Gene name & Chromosome & PUBMED-ID & Trait \\
\hline PMM2 & Phosphomannomutase 2 & 25 & 23759029 & $\begin{array}{c}\text { Daughter pregnancy rate, conception rate } \\
\text { (cow), productive life, protein percent }\end{array}$ \\
MARVELD1 & $\begin{array}{c}\text { MARVEL domain-containing } \\
1\end{array}$ & 26 & 23759029 & Daughter pregnancy rate \\
GRIA3 & $\begin{array}{l}\text { Glutamate receptor, inotropic, } \\
\text { AMPA3 }\end{array}$ & $\mathrm{X}$ & 21831322 & Daughter pregnancy rate \\
& & & & 2011 \\
\hline
\end{tabular}

studies [30, 80, 133, 149]. In humans this gene is expressed in the placenta and has been suggested to have a role in the initiation of parturition [21]. In a GWAS study for calving traits in Danish and Swedish cows, the majority of the identified QTL showed an effect on more than one calving trait (such as birth index, stillbirth, calving ease, calf survival and calving index) [133]. The sharing of regions among fertility traits can reflect the similarity of some of the assessment procedures. For example, the number of inseminations per conception (number of insemination) is related to the days from first to last insemination (which measure time between first and last insemination) [57]. It also likely reflects, as with the overlap among production traits, shared mechanisms.

Perhaps the most interesting and challenging genes and variants are those that affect production and fertility. The success in increasing production in high-producing dairy cows is accompanied by a decline in reproductive performance, first service pregnancy rate and reproductive efficiency $[95,120,152]$. Cows with higher milk production at day 56 post-partum were shown to have significantly a longer commencement of luteal activity post-partum and a shorter first luteal phase [130]. There is an antagonistic relationship between production and fertility traits due to pleiotropic gene effects, linkage or complex physiological associations [68, 152]. For example, a region with effects on both production and fertility traits was reported on chromosome 5 [52, 79, 111, 119, 132]. The significant variants identified in this region (at $87-100 \mathrm{Mb}$ on chromosome 5) were reported to be associated with $\mathrm{C} 22: 1$ milk fatty acid content, milk fat yield [52, 132], protein yield [28], calving to first service interval [111] and sire conception rate in Angus, Brown Swiss and Holstein cattle $[60,117]$. Several candidate genes were reported within this region including ST8SIA1, ABCC9, GABARAPL1 and SLO1C1 [111, 119]. The ABCC9 gene is thought to form ATP-sensitive potassium channels in cardiac, vascular and non-vascular smooth muscles (Gene ID: 10060). This gene is reported as a potential inhibitor of human myometrial contractility [32] through opening ATP-sensitive potassium channels, flowing $\mathrm{K}^{+}$ion and reducing cellular excitability [76], and was speculated to be a candidate gene in dairy cattle for calving to first service interval [111]. This gene has also been reported to be associated with protein yield in dairy cattle in Holstein cattle [28, 111]. Olsen et al. [113], reported a region on chromosome 12 significant for nonreturn rate in Norwegian Red cattle previously reported to be associated with several milk production traits (milk, fat and protein yield). They showed that the most significant SNP in this region had a positive effect on milk traits and a negative effect on non-return rate (mainly for cows returning to oestrus after insemination) [113]. A GWAS of fertility and production traits in Italian Holstein cattle revealed one SNP on chromosome 5 (at $199 \mathrm{Mb}$ ) associated with protein yield, calving interval, fertility index, angularity and days to first service [107]. This SNP (BTA27242-no-rs) was reported with a positive effect for protein yield but had negative effects on calving interval, fertility index, days to first service and angularity, and is not located within any gene, however five genes (DUSP6, POC1B, ATP2B1, C12orf12, EPYC) were reported within $1 \mathrm{Mb}$ of the SNP [107]. In another recent GWAS study using imputed whole-genome sequenced data, [65] identified SNPs in five genes (ENSBTAG00000034643, GBF1, TMEM180, ACTR1B and bta-mir-146b) associated with both fertility and milk yield. GBF1 and bta-mir-146b may influence fat yield through a gene network linked to lipid and carbohydrate metabolism and to reproduction through a network connected to inflammatory response and cell-tocell signalling [65]. The authors suggest that application of whole-genome sequence data in GWAS analysis along with gene network and pathway information may help to better identify candidate genes and variations affecting multiple production and fertility traits and indicates possible pathways that correlate these traits.

\section{Conclusion}

Genetic selection in the dairy industry has contributed to impressive gains in productivity that will help address increasing demand for milk and milk products. Knowledge of the biology of lactation including the key tissues, metabolic pathways, hormones and genes that are involved 
can help researchers identify the underlying variants that contribute to phenotypic differences. Indeed, association studies have highlighted several polymorphisms potentially accounting for variation in production and fertility traits. Continued studies of gene function and expression in the context of lactation and reproduction in cattle and other species will likely improve our ability to identify causative genes and variants for these traits, and may eventually lead to more accurate approaches to genomic selection that work better across generations and breeds.

\section{Motivation}

- The information provided in this review will facilitate interpretation of the biology underlying QTL associated with milk production and fertility-related traits through highlighting tissues, metabolic pathways and genes known to play important roles in lactation in dairy cows.

- Studies of gene function in the context of lactation and reproduction in cattle and other species will likely improve our ability to identify causative genes and variants for these traits.

- Knowledge of possible causative genes and subsequently discovery of new target markers within target regions and genes can be used to increase accuracy of QTL detection and genomic prediction for milk production and fertility traits in dairy cattle, as well as lead to an improved understanding of the process of lactation.

- Increasing the accuracy of genetic selection in the dairy industry will help address increasing demand for milk and milk products.

Open Access This article is distributed under the terms of the Creative Commons Attribution 4.0 International License (http://crea tivecommons.org/licenses/by/4.0/), which permits unrestricted use, distribution, and reproduction in any medium, provided you give appropriate credit to the original author(s) and the source, provide a link to the Creative Commons license, and indicate if changes were made.

\section{References}

1. Ahmadzadeh A, Barnes M, Pearson R (1998) Effect of naloxone on serum luteinizing hormone concentration in anovulatory holstein cows during the early postpartum period. Domest Anim Endocrinol 15:177-181. doi:10.1016/S0739-7240(98)00005-8

2. Arranz JJ, Coppieters W, Berzi P et al (1998) A QTL affecting milk yield and composition maps to bovine chromosome 20: a confirmation. Anim Genet 29:107-115. doi:10.1046/j.13652052.1998.00307.x

3. Ashwell MS, Heyen DW, Sonstegard TS et al (2004) Detection of quantitative trait loci affecting milk production, health, and reproductive traits in Holstein cattle. J Dairy Sci 87:468-475. doi:10.3168/jds.S0022-0302(04)73186-0
4. Baik M, Etchebarne BE, Bong J, VandeHaar MJ (2009) Gene expression profiling of liver and mammary tissues of lactating dairy cows. Asian-Aust J Anim Sci 22:871-884

5. Bauman DE, Currie WB (1980) Partitioning of nutrients during pregnancy and lactation: a review of mechanisms involving homeostasis and homeorhesis. J Dairy Sci 63:1514-1529. doi:10.3168/jds.S0022-0302(80)83111-0

6. Bauman DE, Griinari JM (2001) Regulation and nutritional manipulation of milk fat: low-fat milk syndrome. Livest Prod Sci 70:15-29. doi:10.1016/S0301-6226(01)00195-6

7. Bauman DE, Griinari JM (2003) Nutritional regulation of milk fat synthesis. Annu Rev Nutr 23:203-227. doi:10.1146/annurev. nutr.23.011702.073408

8. Bauman DE, Mather IH, Wall RJ, Lock AL (2006) Major advances associated with the biosynthesis of milk. J Dairy Sci 89:1235-1243. doi:10.3168/jds.S0022-0302(06)72192-0

9. Beigneux AP, Vergnes L, Qiao X et al (2006) Agpat6-a novel lipid biosynthetic gene required for triacylglycerol production in mammary epithelium. J Lipid Res 47:734-744. doi:10.1021/ ja8019214.Optimization

10. Bell AW (1995) Regulation of organic nutrient late pregnancy metabolism during transition from to early lactation. J Anim Sci 73:2804-2819. doi: $10.2527 / 1995.7392804 x$

11. Bell AW, Bauman DE (1997) Adaptations of glucose metabolism during pregnancy and lactation. J Mammary Gland Biol Neoplasia 2:265-278

12. Berg J, Tymoczko J, Stryer L (2002) Biochemistry, 5th edn. W H Freeman, New York

13. Bernard L, Leroux C, Chilliard Y (2008) Bioactive components of milk. Springer, New York

14. Bionaz M, Loor JJ (2008) Gene networks driving bovine milk fat synthesis during the lactation cycle. BMC Genomics 9:366. doi:10.1186/1471-2164-9-366

15. Bionaz M, Loor JJ (2008) ACSL1, AGPAT6, FABP3, LPIN1, and SLC27A6 are the most abundant isoforms in bovine mammary tissue and their expression is affected by stage of lactation. J Nutr 138:1019-1024

16. Bionaz M, Loor JJ (2012) Ruminant metabolic systems biology: reconstruction and integration of transcriptome dynamics underlying functional responses of tissues to nutrition and physiological state. Gene Regul Syst Bio 6:109-125. doi:10. 4137/GRSB.S9852

17. Block SS, Butler WR, Ehrhardt RA et al (2001) Decreased concentration of plasma leptin in periparturient dairy cows is caused by negative energy balance. J Endocrinol 171:339-348. doi:10.1677/joe.0.1710339

18. Blott S, Kim J, Moisio S et al (2003) Molecular dissection of a quantitative trait locus: a phenylalanine-to-tyrosine substitution in the transmembrane domain of the bovine growth hormone receptor is associated with a major effect on milk yield and composition. Genetics 163:253-266

19. Blum JW, Kunz P, Leuenberger H et al (1983) Thyroid hormones, blood plasma metabolites and haematological parameters in relationship to milk yield in dairy cows. Anim Prod 36:93-104. doi:10.1017/S0003356100039982

20. Bouwman AC, Bovenhuis H, Visker MH, van Arendonk JA (2011) Genome-wide association of milk fatty acids in Dutch dairy cattle. BMC Genet 12:43. doi:10.1186/1471-2156-12-43

21. Brinkman-Van Der Linden ECM, Hurtado-Ziola N, Hayakawa $\mathrm{T}$ et al (2007) Human-specific expression of Siglec-6 in the placenta. Glycobiology 17:922-931. doi:10.1093/glycob/ cwm065

22. Burgos SA, Cant JP (2010) IGF-1 stimulates protein synthesis by enhanced signaling through mTORC1 in bovine mammary epithelial cells. Domest Anim Endocrinol 38:211-221. doi:10. 1016/j.domaniend.2009.10.005 
23. Carlson DB, McFadden JW, D'Angelo A et al (2007) Dietary 1-carnitine affects periparturient nutrient metabolism and lactation in multiparous cows. J Dairy Sci 90:3422-3441. doi:10. 3168/jds.2006-811

24. Cerri RLA, Thompson IM, Kim IH et al (2012) Effects of lactation and pregnancy on gene expression of endometrium of Holstein cows at day 17 of the estrous cycle or pregnancy. J Dairy Sci 95:5657-5675. doi:10.3168/jds.2011-5114

25. Chamberlain AJ, Hayes BJ, Savin K et al (2012) Validation of single nucleotide polymorphisms associated with milk production traits in dairy cattle. J Dairy Sci 95:864-875. doi:10.3168/ jds.2010-3786

26. Chatterjee S, Szustakowski JD, Nanguneri NR et al (2009) Identification of novel genes and pathways regulating SREBP transcriptional activity. PLoS ONE 4:e5197. doi:10.1371/jour nal.pone.0005197

27. Chmuzynska A (2006) The multigene family of fatty acidbinding proteins (FABPs): function, structure and polymorphism. J Appl Genet 47:39-48

28. Cochran SD, Cole JB, Null DJ, Hansen PJ (2013) Discovery of single nucleotide polymorphisms in candidate genes associated with fertility and production traits in Holstein cattle. BMC Genet 14:49. doi:10.1186/1471-2156-14-49

29. Cohen-Zinder M, Seroussi E, Larkin DM et al (2005) Identification of a missense mutation in the bovine ABCG2 gene with a major effect on the QTL on chromosome 6 affecting milk yield and composition in Holstein cattle. Genome Res 15:936-944. doi:10.1101/gr.3806705

30. Cole JB, VanRaden PM, O'Connell JR et al (2009) Distribution and location of genetic effects for dairy traits. J Dairy Sci 92:2931-2946. doi:10.3168/jds.2008-1762

31. Coleman RA, Lewin TM, Van Horn CG, Gonzalez-Baró MR (2002) Do long-chain acyl-CoA synthetases regulate fatty acid entry into synthetic versus degradative pathways? J Nutr 132:2123-2126

32. Curley M, Cairns MT, Friel AM et al (2002) Expression of mRNA transcripts for ATP-sensitive potassium channels in human myometrium. Mol Hum Reprod 8:941-945

33. Dann HM, Drackley JK (2005) Carnitine palmitoyltransferase I in liver of periparturient dairy cows: effects of prepartum intake, postpartum induction of ketosis, and periparturient disorders. J Dairy Sci 88:3851-3859. doi:10.3168/jds.S00220302(05)73070-8

34. Dekkers JC (2004) Commercial application of marker- and gene-assisted selection in livestock: strategies and lessons. J Anim Sci 82:313-328

35. Djoković R, Cincović M, Kurćubić V et al (2014) Endocrine and metabolic status of dairy cows during transition period. Thai $\mathbf{J}$ Vet Med Thai J Vet Med 44:59-66

36. Djoković R, Šamanc H, Jovanović M, Nikolić Z (2007) Blood concentrations of thyroid hormones and lipids and content of lipids in the liver of dairy cows in transitional period. Acta Vet Brno 76:525-532. doi:10.2754/avb200776040525

37. Drackley JK (1999) Biology of dairy cows during the transition period: the final frontier? J Dairy Sci 82:2259-2273. doi:10. 3168/jds.S0022-0302(99)75474-3

38. Duplus E, Glorian M, Forest C (2000) Fatty acid regulation of gene transcription. J Biol Chem 275:30749-30752. doi:10.1074/ jbc.R000015200

39. Etherton TD, Bauman DE (1998) Biology of somatotropin in growth and lactation of domestic animals. Physiol Rev 78:745-761

40. Fazioli F, Minichiello L, Matoska V et al (1993) Eps8, a substrate for the epidermal growth factor receptor kinase, enhances EGF-dependent mitogenic signals. EMBO J 12:3799-3808
41. Fenwick MA, Llewellyn S, Fitzpatrick R et al (2008) Negative energy balance in dairy cows is associated with specific changes in IGF-binding protein expression in the oviduct. Reproduction 135:63-75. doi:10.1530/REP-07-0243

42. Fielding BA, Frayn KN (1998) Lipoprotein lipase and the disposition of dietary fatty acids. Br J Nutr 80:495-502. doi:10. 1111/j.1748-1716.2010.02128.x

43. Frolov A, Cho TH, Murphy EJ, Schroeder F (1997) Isoforms of rat liver fatty acid binding protein differ in structure and affinity for fatty acids and fatty acyl CoAs. Biochemistry 36:6545-6555. doi:10.1021/bi970205t

44. Georges M, Georges M, Nielsen D et al (1995) Mapping quantitative trait loci controlling milk production in dairy cattle by exploiting progeny testing. Genet Soc Am 139:907-920

45. Gimeno RE, Cao J (2008) Thematic review series: glycerolipids. Mammalian glycerol-3-phosphate acyltransferases: new genes for an old activity. J Lipid Res 49:2079-2088. doi:10.1194/jlr. R800013-JLR200

46. Goddard ME, MacLeod L., Kemper K et al (2014) A research plan for the identification of QTL. In: Proceeding, 10th world congress of genetics applied to livestock production

47. Goff JP, Horst RL (1997) Physiological changes at parturition and their relationship to metabolic disorders. J Dairy Sci 80:1260-1268. doi:10.3168/jds.S0022-0302(97)76055-7

48. Graber M, Kohler S, Müller A et al (2012) Identification of plasma and hepatic parameters related to metabolic robustness in dairy cows. J Anim Physiol Anim Nutr (Berl) 96:75-84. doi:10.1111/j.1439-0396.2010.01124.x

49. Grisart B, Coppieters W, Farnir F et al (2002) Positional candidate cloning of a QTL in dairy cattle: identification of a missense mutation in the bovine DGAT gene with major effect on milk yield and composition. Genome Res 12:222-231. doi:10.1101/gr.224202

50. Gross JJ, Kessler EC, Albrecht C, Bruckmaier RM (2015) Response of the cholesterol metabolism to a negative energy balance in dairy cows depends on the lactational stage. PLoS ONE 10:e0121956. doi:10.1371/journal.pone.0121956

51. Grummer RR (2007) Strategies to improve fertility of high yielding dairy farms: management of the dry period. Theriogenology 68:281-288. doi:10.1016/j.theriogenology.2007.04. 031

52. Guo J, Jorjani H, Carlborg Ö (2012) A genome-wide association study using international breeding-evaluation data identifies major loci affecting production traits and stature in the Brown Swiss cattle breed. BMC Genet 13:82. doi:10.1186/1471-215613-82

53. Ha N-T, Gross JJ, van Dorland A et al (2015) Gene-based mapping and pathway analysis of metabolic traits in dairy cows. PLoS ONE 10:e0122325. doi:10.1371/journal.pone.0122325

54. Hanson RW, Reshef L (2003) Glyceroneogenesis revisited. Biochimie 85:1199-1205. doi:10.1016/j.biochi.2003.10.022

55. Heid HW, Keenan TW (2005) Intracellular origin and secretion of milk fat globules. Eur J Cell Biol 84:245-258. doi:10.1016/j. ejcb.2004.12.002

56. Höglund JK, Buitenhuis AJ, Guldbrandtsen B et al (2009) Overlapping chromosomal regions for fertility traits and production traits in the Danish Holstein population. J Dairy Sci 92:5712-5719. doi:10.3168/jds.2008-1964

57. Höglund JK, Buitenhuis B, Guldbrandtsen B et al (2015) Genome-wide association study for female fertility in Nordic Red cattle. BMC Genet 16:110. doi:10.1186/s12863-015-0269-x

58. Höglund JK, Guldbrandtsen B, Lund MS, Sahana G (2012) Analyzes of genome-wide association follow-up study for calving traits in dairy cattle. BMC Genet 13:71. doi:10.1186/ 1471-2156-13-71 
59. Höglund JK, Sahana G, Brøndum RF et al (2014) Fine mapping QTL for female fertility on BTA04 and BTA13 in dairy cattle using HD SNP and sequence data. BMC Genom 15:790. doi:10. 1186/1471-2164-15-790

60. Höglund JK, Sahana G, Guldbrandtsen B, Lund MS (2014) Validation of associations for female fertility traits in Nordic Holstein, Nordic Red and Jersey dairy cattle. BMC Genet 15:8. doi:10.1186/1471-2156-15-8

61. Horton JD, Shimomura I, Brown MS et al (1998) Activation of cholesterol synthesis in preference to fatty acid synthesis in liver and adipose tissue of transgenic mice overproducing sterol regulatory element-binding protein-2. J Clin Invest 101:2331-2339. doi:10.1172/JCI2961

62. Hsieh C-W, Huang C, Bederman I et al (2011) Function of phosphoenolpyruvate carboxykinase in mammary gland epithelial cells. J Lipid Res 52:1352-1362. doi:10.1194/jlr.M012666

63. Hu J, Zhang Z, Shen W-J, Azhar S (2010) Cellular cholesterol delivery, intracellular processing and utilization for biosynthesis of steroid hormones. Nutr Metab (Lond) 7:47. doi:10.1186/ 1743-7075-7-47

64. Hunt CR, Ro JH, Dobson DE et al (1986) Adipocyte P2 gene: developmental expression and homology of $5^{\prime}$-flanking sequences among fat cell-specific genes. Proc Natl Acad Sci USA 83:3786-3790. doi:10.1073/pnas.83.11.3786

65. Iso-Touru T, Sahana G, Guldbrandtsen B et al (2016) Genomewide association analysis of milk yield traits in Nordic Red Cattle using imputed whole genome sequence variants. BMC Genet 17:55. doi:10.1186/s12863-016-0363-8

66. Jorritsma R, Wensing T, Kruip AM et al (2003) Metabolic changes in early lactation and impaired reproductive performance in diary cows. Vet Res 34:11-26. doi:10.1051/vetres

67. Jump DB, Botolin D, Wang Y et al (2005) Fatty acid regulation of hepatic. J Nutr 135:2503-2506

68. Kadarmideen HN, Thompson R, Simm G (2000) Linear and threshold model genetic parameters for disease, fertility and milk production in dairy cattle. Anim Sci 71:411-419

69. Kasagic D, Radojicic B, Gvozdic D et al (2011) Endocrine and metabolic profile in Holstein and red Holstein heifers during peripartal period. Acta Vet Brno 61:555-565. doi:10.2298/ AVB1106555K

70. Kawaguchi T, Osatomi K, Yamashita H et al (2002) Mechanism for fatty acid "sparing" effect on glucose-induced transcription: regulation of carbohydrate-responsive element-binding protein by AMP-activated protein kinase. J Biol Chem 277:3829-3835. doi:10.1074/jbc.M107895200

71. Kay JK, Weber WJ, Moore CE et al (2005) Effects of week of lactation and genetic selection for milk yield on milk fatty acid composition in Holstein cows. J Dairy Sci 88:3886-3893. doi:10.3168/jds.S0022-0302(05)73074-5

72. Keenan TW, Mather IH (2009) Intracellular origin of milk fat globules and the nature of the milk fat globule membrane. Adv Dairy Chem 2:137-171. doi:10.1007/0-387-28813-9_4

73. Kemper KE, Reich CM, Bowman PJ et al (2015) Improved precision of QTL mapping using a nonlinear Bayesian method in a multi-breed population leads to greater accuracy of acrossbreed genomic predictions. Genet Sel Evol 47:1-17. doi:10. 1186/s12711-014-0074-4

74. Kessler EC, Gross JJ, Bruckmaier RM, Albrecht C (2014) Cholesterol metabolism, transport, and hepatic regulation in dairy cows during transition and early lactation. J Dairy Sci 97:5481-5490. doi:10.3168/jds.2014-7926

75. Khan MJ, Hosseini A, Burrell S et al (2013) Change in subcutaneous adipose tissue metabolism and gene network expression during the transition period in dairy cows, including differences due to sire genetic merit. J Dairy Sci 96:2171-2182. doi:10. 3168/jds.2012-5794
76. Khan RN, Matharoo-Ball B, Arulkumaran S, Ashford ML (2001) Potassium channels in the human myometrium. Exp Physiol 86:255-264

77. Khatkar MS, Thomson PC, Tammen I, Raadsma HW (2004) Quantitative trait loci mapping in dairy cattle: review and metaanalysis. Genet Sel Evol 36:163-190. doi:10.1186/1297-968636-2-163

78. Knight PG, Glister C (2006) TGF-beta superfamily members and ovarian follicle development. Reproduction 132:191-206. doi:10.1530/rep.1.01074

79. Kolbehdari D, Wang Z, Grant JR et al (2009) A whole genome scan to map QTL for milk production traits and somatic cell score in Canadian Holstein bulls. J Anim Breed Genet 126:216-227. doi:10.1111/j.1439-0388.2008.00793.x

80. Kuehn C, Bennewitz J, Reinsch N et al (2003) Quantitative trait loci mapping of functional traits in the German Holstein cattle population. J Dairy Sci 86:360-368. doi:10.3168/jds.S00220302(03)73614-5

81. Laliotis GP, Bizelis I, Rogdakis E (2010) Comparative approach of the de novo fatty acid synthesis (lipogenesis) between ruminant and non ruminant mammalian species: from biochemical level to the main regulatory lipogenic genes. Curr Genomics 11:168-183. doi:10.2174/138920210791110960

82. Lambeth JD (1986) Cytochrome P-450 scc a review of the specificity and properties of the cholesterol binding site. Endocr Res 12:371-392. doi:10.3109/07435808609035446

83. Laven RA, Scaramuzzi RJ, Wathes DC et al (2007) Recent research on the effects of excess dietary nitrogen on the fertility of dairy cows. Vet Rec 160:359-362. doi:10.1136/vr.160.11.359

84. Lehner R, Kuksis A (1996) Biosynthesis of triacylglycerols. Prog Lipid Res 35:169-201

85. Lemay DG, Neville MC, Rudolph MC et al (2007) Gene regulatory networks in lactation: identification of global principles using bioinformatics. BMC Syst Biol 1:56. doi:10.1186/17520509-1-56

86. Leslie KE (1983) The events of normal and abnormal postpartum reproductive endocrinology and uterine involution in dairy cows: a review. Can Vet J 24:67-71

87. Leury BJ, Baumgard LH, Block SS et al (2003) Effect of insulin and growth hormone on plasma leptin in periparturient dairy cows. Am J Physiol Regul Integr Comp Physiol 285:R1107R1115. doi:10.1152/ajpregu.00320.2003

88. Li X, Li X, Chen H et al (2013) Non-esterified fatty acids activate the AMP-activated protein kinase signaling pathway to regulate lipid metabolism in bovine hepatocytes. Cell Biochem Biophys 67:1157-1169. doi:10.1007/s12013-013-9629-1

89. Lin X-Z, Luo J, Zhang L-P et al (2013) MiR-27a suppresses triglyceride accumulation and affects gene mRNA expression associated with fat metabolism in dairy goat mammary gland epithelial cells. Gene 521:15-23. doi:10.1016/j.gene.2013.03. 050

90. Ling B, Alcorn J (2008) Acute administration of cefepime lowers L-carnitine concentrations in early lactation stage rat milk. J Nutr 138:1317-1322

91. Littlejohn MD, Tiplady K, Fink TA et al (2016) Sequence-based association analysis reveals an MGST1 eQTL with pleiotropic effects on bovine milk composition. Sci Rep. doi:10.5061/dryad. $457 \mathrm{br}$

92. Littlejohn MD, Tiplady K, Lopdell T et al (2014) Expression variants of the lipogenic AGPAT6 gene affect diverse milk composition phenotypes in Bos taurus. PLoS ONE 9:e85757. doi:10.1371/journal.pone.0085757

93. Llewellyn S, Fitzpatrick R, Kenny DA et al (2008) Endometrial expression of the insulin-like growth factor system during uterine involution in the postpartum dairy cow. Domest Anim Endocrinol 34:391-402. doi:10.1016/j.domaniend.2007.11.003 
94. Loor JJ, Everts RE, Bionaz M et al (2007) Nutrition-induced ketosis alters metabolic and signaling gene networks in liver of periparturient dairy cows. Physiol Genomics 32:105-116. doi:10.1152/physiolgenomics.00188.2007

95. Lucy MC (2001) Reproductive loss in high-producing dairy cattle: where will it end? J Dairy Sci 84:1277-1293. doi:10. 3168/jds.S0022-0302(01)70158-0

96. Ma L, Corl BA (2012) Transcriptional regulation of lipid synthesis in bovine mammary epithelial cells by sterol regulatory element binding protein-1. J Dairy Sci 95:3743-3755. doi:10. 3168/jds.2011-5083

97. Mach N, Blum Y, Bannink A et al (2012) Pleiotropic effects of polymorphism of the gene diacylglycerol- $O$-transferase 1 (DGAT1) in the mammary gland tissue of dairy cows. J Dairy Sci 95:4989-5000. doi:10.3168/jds.2012-5348

98. Mandard S, Müller M, Kersten S (2004) Peroxisome proliferator-activated receptor a target genes. Cell Mol Life Sci 61:393-416. doi:10.1007/s00018-003-3216-3

99. Mannaerts GP, Debeer LJ, Thomas J, De Schepper PJ (1979) Mitochondrial and peroxisomal fatty acid oxidation in liver homogenates and isolated hepatocytes from control and clofibrate-treated rats. J Biol Chem 254:4585-4595

100. Maxa J, Neuditschko M, Russ I et al (2012) Genome-wide association mapping of milk production traits in Braunvieh cattle. J Dairy Sci 95:5357-5364. doi:10.3168/jds.2011-4673

101. Mcarthur MJ, Atshaves BP, Frolov A et al (1999) Cellular uptake and intracellular trafficking of long chain fatty acids. J Lipid Res 40:1371-1383

102. McGarry JD, Brown NF (1997) The mitochondrial carnitine palmitoyltransferase system. From concept to molecular analysis. Eur J Biochem 244:1-14. doi:10.1111/j.1432-1033.1997. 00001.x

103. McNamara JP (1988) Regulation of bovine adipose tissue metabolism during lactation. 4. Dose-responsiveness to epinephrine as altered by stage of lactation. J Dairy Sci 71:643-649. doi:10.3168/jds.S0022-0302(88)79602-2

104. McNamara JP, Murray CE (2001) Sympathetic nervous system activity in adipose tissues during pregnancy and lactation of the rat. J Dairy Sci 84:1382-1389. doi:10.3168/jds.S00220302(01)70169-5

105. Meredith BK, Kearney FJ, Finlay EK et al (2012) Genome-wide associations for milk production and somatic cell score in Holstein-Friesian cattle in Ireland. BMC Genet 13:21. doi:10. 1186/1471-2156-13-21

106. Meuwissen THE, Hayes BJ, Goddard ME (2001) Prediction of total genetic value using genome-wide dense marker maps. Genetics 157:1819-1829

107. Minozzi G, Nicolazzi EL, Stella A et al (2013) Genome wide analysis of fertility and production traits in Italian Holstein cattle. PLoS ONE 8:e80219. doi:10.1371/journal.pone.0080219

108. Miyoshi H, Perfield JW, Souza SC et al (2007) Control of adipose triglyceride lipase action by serine 517 of perilipin A globally regulates protein kinase a-stimulated lipolysis in adipocytes. J Biol Chem 282:996-1002. doi:10.1074/jbc. M605770200

109. Mootha VK, Lindgren CM, Eriksson K-F et al (2003) PGC1alpha-responsive genes involved in oxidative phosphorylation are coordinately downregulated in human diabetes. Nat Genet 34:267-273. doi:10.1038/ng1180

110. Mullen MP, Berry DP, Howard DJ et al (2011) Single nucleotide polymorphisms in the insulin-like growth factor 1 (IGF-1) gene are associated with performance in Holstein-Friesian dairy cattle. Front Genet 2:1-9. doi:10.3389/fgene.2011.00003

111. Nayeri S, Sargolzaei M, Abo-Ismail MK et al (2016) Genomewide association for milk production and female fertility traits in
Canadian dairy Holstein cattle. BMC Genet 17:75. doi:10.1186/ s12863-016-0386-1

112. Nguyen P, Leray V, Diez M et al (2008) Liver lipid metabolism. J Anim Physiol Anim Nutr (Berl) 92:272-283. doi:10.1111/j. 1439-0396.2007.00752.x

113. Olsen HG, Hayes BJ, Kent MP et al (2011) Genome-wide association mapping in Norwegian Red cattle identifies quantitative trait loci for fertility and milk production on BTA12. Anim Genet 42:466-474. doi:10.1111/j.1365-2052.2011.02179. $\mathrm{x}$

114. Ong EC, Nesin V, Long CL et al (2013) A TRPC1 proteindependent pathway regulates osteoclast formation and function. J Biol Chem 288:22219-22232. doi:10.1074/jbc.M113.459826

115. Patti ME, Butte AJ, Crunkhorn S et al (2003) Coordinated reduction of genes of oxidative metabolism in humans with insulin resistance and diabetes: potential role of PGC1 and NRF1. Proc Natl Acad Sci USA 100:8466-8471. doi:10.1073/ pnas. 1032913100

116. Payne AH, Hales DB (2004) Overview of steroidogenic enzymes in the pathway from cholesterol to active steroid hormones. Endocr Rev 25:947-970. doi:10.1210/er.2003-0030

117. Peñagaricano F, Weigel KA, Khatib H (2012) Genome-wide association study identifies candidate markers for bull fertility in Holstein dairy cattle. Anim Genet 43:65-71. doi:10.1111/j. 1365-2052.2012.02350.x

118. Pezzi C, Accorsi PA, Vigo D et al (2003) 5'-Deiodinase activity and circulating thyronines in lactating cows. J Dairy Sci 86:152-158. doi:10.3168/jds.S0022-0302(03)73595-4

119. Pimentel ECG, Bauersachs S, Tietze M et al (2011) Exploration of relationships between production and fertility traits in dairy cattle via association studies of SNPs within candidate genes derived by expression profiling. Anim Genet 42:251-262 . doi:10.1111/j.1365-2052.2010.02148.x

120. Pryce JE, Royal MD, Garnsworthy PC, Mao IL (2004) Fertility in the high-producing dairy cow. Livest Prod Sci 86:125-135. doi:10.1016/S0301-6226(03)00145-3

121. Puigserver P, Spiegelman BM (2003) Peroxisome proliferatoractivated receptor-gamma coactivator 1 alpha (PGC-1alpha): transcriptional coactivator and metabolic regulator. Endocr Rev 24:78-90. doi:10.1210/er.2002-0012

122. Raven L-A, Cocks BG, Goddard ME et al (2014) Genetic variants in mammary development, prolactin signalling and involution pathways explain considerable variation in bovine milk production and milk composition. Genet Sel Evol 46:29. doi:10.1186/1297-9686-46-29

123. Raven L-A, Cocks BG, Hayes BJ (2014) Multibreed genome wide association can improve precision of mapping causative variants underlying milk production in dairy cattle. BMC Genom 15:62. doi:10.1186/1471-2164-15-62

124. Reist M, Erdin D, von Euw D et al (2002) Estimation of energy balance at the individual and herd level using blood and milk traits in high-yielding dairy cows. J Dairy Sci 85:3314-3327. doi:10.3168/jds.S0022-0302(02)74420-2

125. Reshef L, Olswang Y, Cassuto H et al (2003) Glyceroneogenesis and the triglyceride/fatty acid cycle. J Biol Chem 278:30413-30416. doi:10.1074/jbc.R300017200

126. Reue K, Dwyer JR (2008) Lipin proteins and metabolic homeostasis. J Lipid Res 50:S109-S114. doi:10.1194/jlr.R800052JLR200

127. Reverter A, Fortes MRS (2012) Building single nucleotide polymorphism-derived gene regulatory networks: towards functional genomewide association studies. J Anim Sci 91:530-536. doi:10.2527/jas.2012-5780

128. Rhoads ML, Gilbert RO, Lucy MC, Butler WR (2004) Effects of urea infusion on the uterine luminal environment of dairy cows. 
J Dairy Sci 87:2896-2901. doi:10.3168/jds.S00220302(04)73420-7

129. Roche JR, Friggens NC, Kay JK et al (2009) Invited review: body condition score and its association with dairy cow productivity, health, and welfare. J Dairy Sci 92:5769-5801. doi:10. 3168/jds.2009-2431

130. Royal MD, Flint APF, Woolliams JA (2002) Genetic and phenotypic relationships among endocrine and traditional fertility traits and production traits in Holstein-Friesian dairy cows. J Dairy Sci 85:958-967. doi:10.3168/jds.S0022-0302(02)741556

131. Rudolph MC, McManaman JL, Phang T et al (2007) Metabolic regulation in the lactating mammary gland: a lipid synthesizing machine. Physiol Genomics 28:323-336. doi:10.1152/phy siolgenomics.00020.2006

132. Saatchi M, Garrick DJ, Tait RG et al (2013) Genome-wide association and prediction of direct genomic breeding values for composition of fatty acids in Angus beef cattle. BMC Genomic 14:730. doi:10.1186/1471-2164-14-730

133. Sahana G, Guldbrandtsen B, Lund MS (2011) Genome-wide association study for calving traits in Danish and Swedish Holstein cattle. J Dairy Sci 94:479-486. doi:10.3168/jds.20103381

134. Schillo KK, Halls JB, Hileman SM (1992) Effects of nutrition and season in the onset of puberty in the beef heifer. J Anim Sci 70:3994-4005

135. Schlegel G, Keller J, Hirche F et al (2012) Expression of genes involved in hepatic carnitine synthesis and uptake in dairy cows in the transition period and at different stages of lactation. BMC Vet Res 8:28. doi:10.1186/1746-6148-8-28

136. Shindou H, Hishikawa D, Harayama $T$ et al (2008) Recent progress on acyl CoA: lysophospholipid acyltransferase research. J Lipid Res 50:S46-S51. doi:10.1194/jlr.R800035JLR200

137. Sinclair KD, Sinclair LA, Robinson JJ (2000) Nitrogen metabolism and fertility in cattle: I. Adaptive changes in intake and metabolism to diets differing in their rate of energy and nitrogen release in the rumen. J Anim Sci 78:2659-2669

138. Sivan E, Boden G (2003) Free fatty acids, insulin resistance, and pregnancy. Curr Diab Rep 3:319-322. doi:10.1007/s11892-0030024-y

139. Snelling WM, Cushman RA, Keele JW et al (2013) Networks and pathways to guide genomic selection. J Anim Sci 91:537-552. doi:10.2527/jas2012-5784

140. Solovieff N, Cotsapas C, Lee PH et al (2013) Pleiotropy in complex traits: challenges and strategies. Nat Rev Genet 14:483-495. doi:10.1126/scisignal.2001449.Engineering

141. Spicer LJ, Echternkamp SE (1995) The ovarian insulin and insulin-like growth factor system with an emphasis on domestic animals. Domest Anim Endocrinol 12:223-245. doi:10.1016/ 0739-7240(95)00021-6

142. Stagg K, Spicer LJ, Sreenan JM et al (1998) Effect of calf isolation on follicular wave dynamics, gonadotropin and metabolic hormone changes, and interval to first ovulation in beef cows fed either of two energy levels postpartum. Biol Reprod 59:777-783. doi:10.1095/biolreprod59.4.777

143. Stevenson KR, Wathes DC (1996) Insulin-like growth factors and their binding proteins in the ovine oviduct during the oestrous cycle. J Reprod Fertil 108:31-40. doi:10.1530/jrf.0. 1080031

144. Sumner-Thomson JM, Vierck JL, McNamara JP (2011) Differential expression of genes in adipose tissue of first-lactation dairy cattle. J Dairy Sci 94:361-369. doi:10.3168/jds.2010-3447

145. Sumner JM, McNamara JP (2007) Expression of lipolytic genes in the adipose tissue of pregnant and lactating Holstein dairy cattle. J Dairy Sci 90:5237-5246. doi:10.3168/jds.2007-0307
146. Sutherland KD, Lindeman GJ, Visvader JE (2007) The molecular culprits underlying precocious mammary gland involution. J Mammary Gland Biol Neoplasia 12:15-23. doi:10.1007/ s10911-007-9034-8

147. Takeuchi K, Reue K (2009) Biochemistry, physiology, and genetics of GPAT, AGPAT, and lipin enzymes in triglyceride synthesis. Am J Physiol Endocrinol Metab 296:E1195-E1209. doi:10.1152/ajpendo.90958.2008

148. Taylor VJ, Cheng Z, Pushpakumara PGA et al (2004) Relationships between the plasma concentrations of insulin-like growth factor-I in dairy cows and their fertility and milk yield. Vet Rec 155:583-588. doi:10.1136/vr.155.19.583

149. Thomasen JR, Guldbrandtsen B, Sørensen P et al (2008) Quantitative trait loci affecting calving traits in Danish Holstein cattle. J Dairy Sci 91:2098-2105. doi:10.3168/jds.2007-0602

150. Van den Top AM, Wensing T, Geelen MJ et al (1995) Time trends of plasma lipids and enzymes synthesizing hepatic triacylglycerol during postpartum development of fatty liver in dairy cows. J Dairy Sci 78:2208-2220. doi:10.3168/jds.S00220302(95)76848-5

151. Van Dorland HA, Richter S, Morel I et al (2009) Variation in hepatic regulation of metabolism during the dry period and in early lactation in dairy cows. J Dairy Sci 92:1924-1940. doi:10. 3168/jds.2008-1454

152. Veerkamp RF, Beerda B (2007) Genetics and genomics to improve fertility in high producing dairy cows. Theriogenology 68:266-273. doi:10.1016/j.theriogenology.2007.04.034

153. Vernon RG, Denis RGP, Sørensen A (2001) Signals of adiposity. Domest Anim Endocrinol 21:197-214. doi:10.1016/S07397240(01)00121-7

154. Viitala S, Szyda J, Blott S et al (2006) The role of the bovine growth hormone receptor and prolactin receptor genes in milk, fat and protein production in Finnish Ayrshire dairy cattle. Genetics 173:2151-2164. doi:10.1534/genetics.105.046730

155. Viollet B, Foretz M, Guigas B et al (2006) Activation of AMPactivated protein kinase in the liver: a new strategy for the management of metabolic hepatic disorders. J Physiol 574:41-53. doi:10.1113/jphysiol.2006.108506

156. Viturro E, Koenning M, Kroemer A et al (2009) Cholesterol synthesis in the lactating cow: induced expression of candidate genes. J Steroid Biochem Mol Biol 115:62-67. doi:10.1016/j. jsbmb.2009.02.011

157. Walsh SW, Williams EJ, Evans ACO (2011) A review of the causes of poor fertility in high milk producing dairy cows. Anim Reprod Sci 123:127-138. doi:10.1016/j.anireprosci.2010.12.001

158. Wang X, Wurmser C, Pausch H et al (2012) Identification and dissection of four major QTL affecting milk fat content in the German Holstein-Friesian population. PLoS ONE 7:e40711. doi:10.1371/journal.pone.0040711

159. Wathes DC, Cheng Z, Chowdhury W et al (2009) Negative energy balance alters global gene expression and immune responses in the uterus of postpartum dairy cows. Physiol Genomic. doi:10.1152/physiolgenomics.00064.2009

160. Wathes DC, Cheng Z, Fenwick MA et al (2011) Influence of energy balance on the somatotrophic axis and matrix metalloproteinase expression in the endometrium of the postpartum dairy cow. Reproduction 141:269-281. doi:10.1530/REP-100177

161. Wathes DC, Fenwick M, Cheng Z et al (2007) Influence of negative energy balance on cyclicity and fertility in the high producing dairy cow. Theriogenology 68:232-241. doi:10.1016/ j.theriogenology.2007.04.006

162. Wathes DC, Taylor VJ, Cheng Z, Mann GE (2003) Follicle growth, corpus luteum function and their effects on embryo development in postpartum dairy cows. Reprod Suppl 61:219-237 
163. Weikard R, Goldammer T, Brunner RM, Kuehn C (2012) Tissue-specific mRNA expression patterns reveal a coordinated metabolic response associated with genetic selection for milk production in cows. Physiol Genomics 44:728-739. doi:10. 1152/physiolgenomics.00007.2012

164. Weng L, Macciardi F, Subramanian A et al (2011) SNP-based pathway enrichment analysis for genome-wide association studies. BMC Bioinform 12:99. doi:10.1186/1471-2105-12-99

165. Xie Y, Yang S, Cui X et al (2014) Identification and expression pattern of two novel alternative splicing variants of EEF1D gene of dairy cattle. Gene 534:189-196. doi:10.1016/j.gene.2013.10. 061

166. Yamashita A, Nakanishi H, Suzuki H et al (2007) Topology of acyltransferase motifs and substrate specificity and accessibility in 1-acyl-sn-glycero-3-phosphate acyltransferase 1. Biochim
Biophys Acta 1771:1202-1215. doi:10.1016/j.bbalip.2007.07. 002

167. Zhang Q, Koser SL, Bequette BJ, Donkin SS (2015) Effect of propionate on mRNA expression of key genes for gluconeogenesis in liver of dairy cattle. J Dairy Sci 98:8698-8709. doi:10. 3168/jds.2015-9590

168. Zhou G, Myers R, Li Y et al (2001) Role of AMP-activated protein kinase in mechanism of metformin action. J Clin Invest 108:1167-1174. doi:10.1172/JCI200113505

169. Zhu LH, Armentano LE, Bremmer DR et al (2000) Plasma concentration of urea, ammonia, glutamine around calving, and the relation of hepatic triglyceride, to plasma ammonia removal and blood acid-base balance. J Dairy Sci 83:734-740. doi:10. 3168/jds.S0022-0302(00)74935-6 